Prepared for the U.S. Department of Energy

under Contract DE-AC05-76RL01830

\title{
Characterization and Monitoring Data for Evaluating Constructed Emergent Sandbar Habitat in the Missouri River Mainstem 2004-2009
}

CA Duberstein

April 2011

Pacific Northwest

NATIONAL LABORATORY

Proudly Operated by Battelle Since 1965 


\title{
DISCLAIMER
}

This report was prepared as an account of work sponsored by an agency of the United States Government. Neither the United States Government nor any agency thereof, nor Battelle Memorial Institute, nor any of their employees, makes any warranty, express or implied, or assumes any legal liability or responsibility for the accuracy, completeness, or usefulness of any information, apparatus, product, or process disclosed, or represents that its use would not infringe privately owned rights. Reference herein to any specific commercial product, process, or service by trade name, trademark, manufacturer, or otherwise does not necessarily constitute or imply its endorsement, recommendation, or favoring by the United States Government or any agency thereof, or Battelle Memorial Institute. The views and opinions of authors expressed herein do not necessarily state or reflect those of the United States Government or any agency thereof.

\author{
PACIFIC NORTHWEST NATIONAL LABORATORY \\ operated by \\ BATTELLE \\ for the \\ UNITED STATES DEPARTMENT OF ENERGY \\ under Contract DE-AC05-76RL01830 \\ Printed in the United States of America \\ Available to DOE and DOE contractors from the \\ Office of Scientific and Technical Information, \\ P.O. Box 62, Oak Ridge, TN 37831-0062; \\ ph: (865) 576-8401 \\ fax: (865) $576-5728$ \\ email: reports@adonis.osti.gov \\ Available to the public from the National Technical Information Service, \\ U.S. Department of Commerce, 5285 Port Royal Rd., Springfield, VA 22161 \\ ph: (800) 553-6847 \\ fax: (703) 605-6900 \\ email: orders@ntis.fedworld.gov \\ online ordering: http://www.ntis.gov/ordering.htm
}

This document was printed on recycled paper. 


\title{
Characterization and Monitoring Data for Evaluating Constructed Emergent Sandbar Habitat in the Missouri River Mainstem 2004-2009
}

\author{
CA Duberstein
}

April 2011

Prepared for

the U.S. Army Corps of Engineers, Omaha District under a Related Services Agreement with the U.S. Department of Energy under Contract DE-AC05-76RL01830

Pacific Northwest National Laboratory

Richland, Washington 99352 


\section{Summary}

The U.S. Army Corps of Engineers (Corps) provides the primary operational management of the Missouri River Main Stem Reservoir System. Management of the Missouri River has generally reduced peak river flows that form and maintain emergent sandbar habitat. Emergent sandbars provide nonvegetated nesting habitat for the endangered interior population of the least tern (Sternula antillarum athalassos) and the threatened Northern Great Plains piping plover (Charadrius melodus). The Corps, after formal consultation with the U.S. Fish and Wildlife Service, initiated efforts to create new emergent sandbar habitat and manage existing habitat through the Missouri River Recovery Program.

Investigations of tern and plover ecology and their use of emergent sandbars are ongoing, and are intended to provide information about the effects of management actions aimed at maintaining these species. The objective of this document is to provide a synthesis of information gathered from 2004 through 2009 about the construction and mapping of emergent sandbar habitat, management actions taken, results of tern and plover productivity monitoring, habitat use, and other research activities directed toward use of created and managed habitats.

Since 2000, piping plovers nesting within the Gavins Point reach, Garrison Reach, Lake Oahe, and Lake Sakakawea have fledged the majority of piping plovers produced along the Missouri River System. Habitats within Lewis and Clark Lake have also provided nesting habitat for both terns and plovers and have recently become important plover production areas. Mechanical construction of emergent sandbar habitat (ESH) within some of these reaches of the Missouri River began in 2004. Through 2009, 11 sandbar complexes had been constructed (10 in Gavins Point Reach, 1 in Lewis and Clarke Lake) totaling about 543 ac of piping plover and least tern nesting habitat. Both piping plovers and least terns have successfully nested and fledged young on constructed sandbars. Plover nesting effort on constructed habitats within the Gavins Point Reach and Lewis and Clark Lake has increased each year since 2005, while nesting on natural sandbars has remained fairly constant. Gavins Point habitats are also important for least tern production, and a substantial number of least terns are also fledged on constructed habitats within Lewis and Clark Lake. ESH construction has contributed to the ongoing recovery of both species and has been demonstrated as an ecological alternative for creation of nesting habitat.

Habitat delineation using remotely sensed data was successfully demonstrated and subsequently completed on four reaches of the Missouri River. Satellite imagery, airborne-acquired elevation data, and aerial photography from multiple years were used create and assess the accuracy of a nesting habitat map of the Gavins Point Reach. Approximately 1000 ac of nesting habitat were available in the Gavins Point Reach in 2006 and about 1200 ac in 2007. Constructed habitats contributed between 40 to 150 ac of nesting habitat in 2006, and between 72 to 192 ac of habitat in 2007.

Nest survey and monitoring within the Gavins Point reach reaffirmed the vast majority of plover nests occur on dry sand. Moist sand is the next most important substrate, while vegetated areas are generally avoided by nesting plovers. Along Lake Sakakawea, plovers placed their nests within gravel strips with scattered cobbles and little vegetation and avoided silty substrates. Least terns nesting in these river reaches preferred to nest on coarse substrates and avoided vegetative cover, leaf litter, and silty substrates, although some woody vegetation was tolerated on natural sandbars. The establishment of vegetation following construction may limit the viability of constructed sandbar habitat for nesting. However, plovers have nested within areas where vegetation was controlled. Initial treatments, including herbicide application and mowing had mixed results and those results were short-lived. Habitats sprayed and later 
mowed exceeded reproduction goals during 2005, indicating vegetation control may be a viable management tool. More recent research by the Corps revealed a single application of Imazapyr suppressed 75 to $80 \%$ of vegetation up to 2 years after being applied. The Corps is currently evaluating a number of treatment combinations designed to set back succession on both constructed and natural sandbar habitat, including fall and spring herbicide treatment coupled with various mechanical means to remove or bury dead or dying vegetation. Results of the ongoing vegetation control and removal study should provide additional insight into the mechanisms affecting productivity and longevity of habitat viability.

Piping plover survival models showed fledgling daily survival rates were higher on constructed sandbars than on natural sandbars, indicating that constructed sandbars functioned well as brood-rearing habitat. However, modeled plover survival from one year to the next among constructed and natural sandbars was not consistent with respect to nest density. As nest density increased, apparent survival on constructed sandbars decreased while it increased on natural sandbars. Survival models depend on observation of previously marked individuals. Marked individuals that emigrate before being subsequently observed are difficult to discern from marked individuals that perished and were not observed. Differential rates of emigration from constructed and natural sandbars could contribute significant variability in calculated survival rates.

Study of plover foraging ecology revealed adults prefer to forage for invertebrates on shorelines protected from wind and waves, while plover chicks did not show a preference for protected over exposed shorelines. Chicks foraged in dry, wetted, bare, and vegetated habitats. They fed more often in saturated or moist habitats in some locations even though invertebrate biomass was greater in vegetated habitats. Prey fish populations that terns feed on were characterized adjacent to both constructed and natural sandbars. Four species were dominant and accounted for $60 \%$ of all fish captured. Fish populations did not differ near constructed or natural habitats, but rather related to physical characteristics within the river such as water depth.

ESH construction has resulted in a net gain of tern and plover nesting habitat. Both terns and plovers successfully nest and fledge young on constructed sandbars, and constructed habitats were preferred over natural habitats. However, the preference of constructed sandbars over natural sandbars may be an artifact of sandbar age. Natural processes may limit the viability of all sandbars as nesting habitat. Management of vegetation, both on natural and constructed ESH, could set back succession and provide the necessary disturbance to increase the number of seasons sandbars function optimally as nesting habitat. Continued research may be needed to identify whether changes in constructed sandbar engineering and management increase the length of time constructed habitats effectively function as nesting habitat.

The Corps has funded a significant amount of research on least terns and piping plovers within the Missouri River System. Numerous entities have gathered, compiled, and analyzed life-history data and associated information on these two listed species. Research reports and presentations, publications, and internal Corps reports summarized in this document provide a vast amount of ecological knowledge. Other research plans submitted to the Corps describe additional studies focused on nest site selection, foraging ecology, habitat use, and survival of both terns and plovers. 


\section{Acronyms and Abbreviations}

$\begin{array}{ll}\text { ac } & \text { acre(s) } \\ \text { BiOp } & \text { Biological Opinion } \\ \text { Corps } & \text { U.S. Army Corps of Engineers } \\ \text { DSR } & \text { daily survival rate } \\ \text { ESH } & \text { emergent sandbar habitat } \\ \mathrm{ft} & \text { (foot)feet } \\ \text { ha } & \text { hectare(s) } \\ \text { in. } & \text { inch(es) } \\ \text { kcfs } & \text { thousand cubic feet per second } \\ \text { LIDAR } & \text { Light Detection and Ranging } \\ \mathrm{m} & \text { meter(s) } \\ \mathrm{m}^{2} & \text { square meter(s) } \\ \text { rm } & \text { river mile(s) } \\ \text { RPA } & \text { Reasonable Prudent Alternative } \\ \text { USFWS } & \text { U.S. Fish and Wildlife Service } \\ \text { USGS } & \text { U.S. Geological Survey } \\ \text { yd } & \text { yard(s) }\end{array}$




\section{Contents}

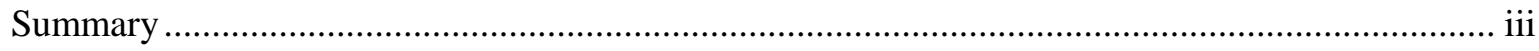

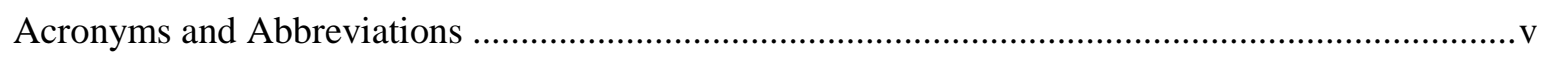

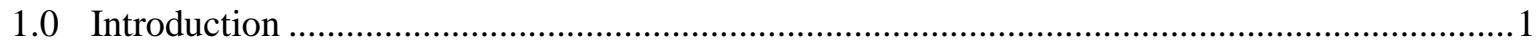

2.0 Emergent Sandbar Habitat Construction ....................................................................

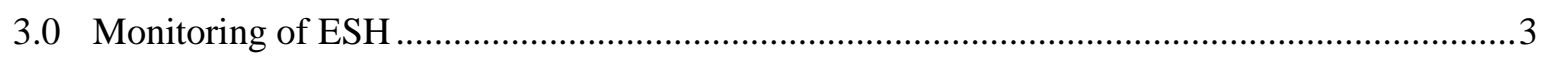

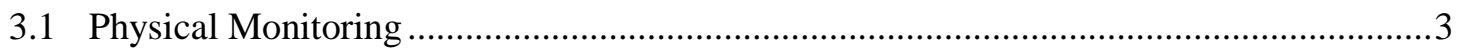

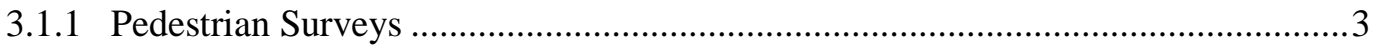

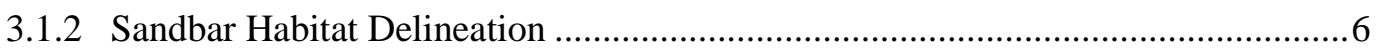

3.1.3 Summary of Physical Monitoring .................................................................. 8

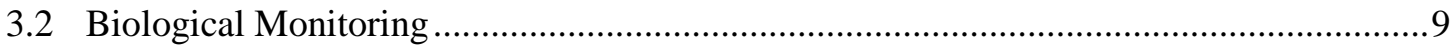

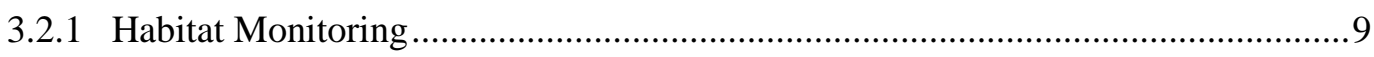

3.2.2 Productivity and Population Monitoring ..............................................................10

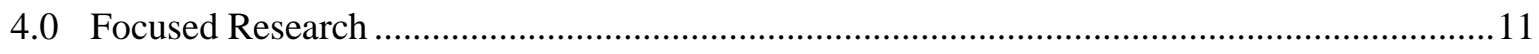

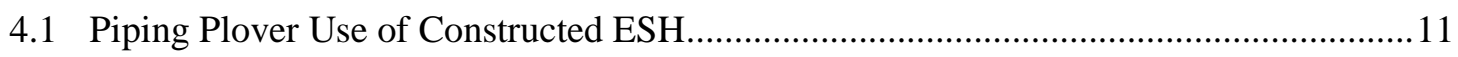

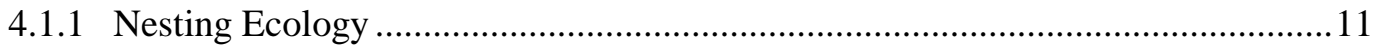

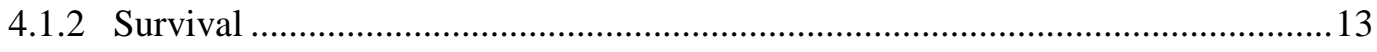

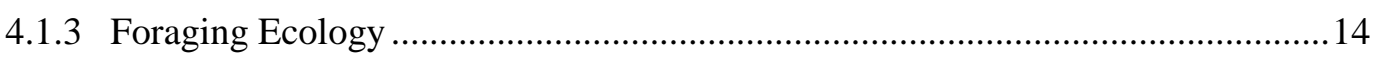

4.2 Least Tern Use of Constructed ESH ………............................................................. 15

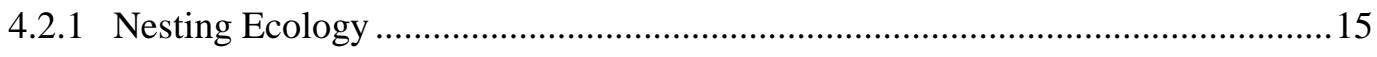

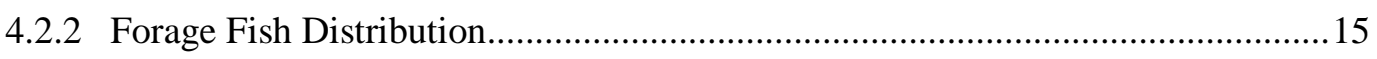

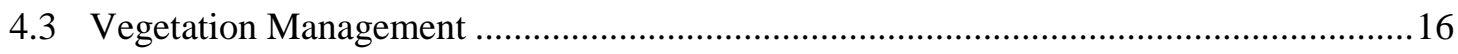

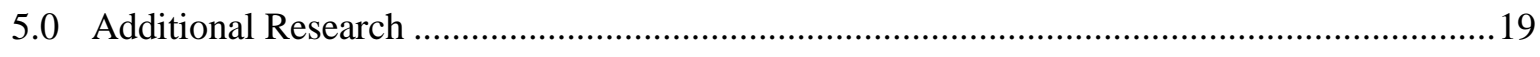

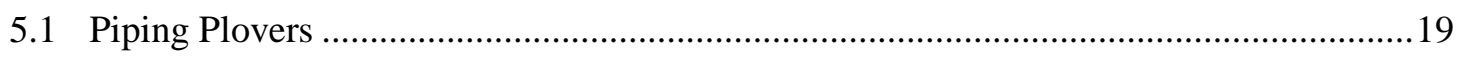

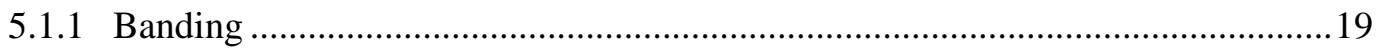

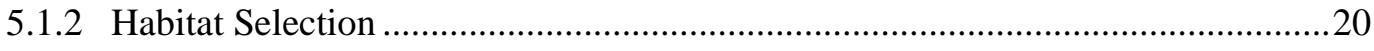

5.1 .3 Population Modeling .................................................................................20

6.0 Implications of ESH Construction and Management Actions on Terns and Plovers ...............20

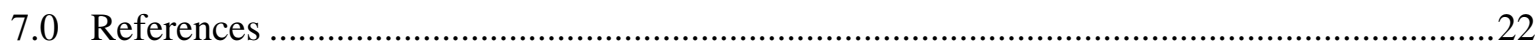




\section{Figures}

Figure 1. Quickbird Image of Site 755.0, Ponca Complex Showing an Example of the Aerial Extent of Erosion Since Construction (Source: Corps 2010) 4

Figure 2. Quickbird Image of Site 761.3 Showing an Example of the Aerial Extent of Erosion Since Construction (Source: Corps 2010).................................................................................

Figure 3. Sum of Piping Plover Fledglings Within Various Reaches of the Missouri River System, 1986-1989 and 2000-2009 (Data Sources: Corps DMS Database and USFWS 1990a)

Figure 4. Sum of Least Tern Fledglings Within Various Reaches of the Missouri River System, 1986-1989 and 2000-2009 (Data Sources: Corps DMS Database and USFWS 1990a) ........11

Figure 5. Piping Plover Use of Nesting Habitat on Monitored Sandbars Within the Gavins Point Reach and Lewis and Clark Lake from 2005 Through 2009 (Sources: Catlin and Fraser 2010a, 2010b, 2010c; Felio et al. 2010a, 2010b)

Figure 6. Piping Plover Use of Nesting Substrates on Monitored Sandbars Within the Gavins Point Reach and Lewis and Clark Lake from 2005 Through 2007 (Sources: Catlin and Fraser 2010a, 2010b, 2010c).

Figure 7. Control of Vegetation by Various Treatments of Lime (Calcium Carbonate) and the Herbicide Imazapyr on Sandbars of Lewis and Clark Lake (Data Source: Datta et al. 2009).17

Figure 8. Control of Vegetation by Various Treatments of Ash (Sodium Carbonate) and the Herbicide Imazapyr on Sandbars of Lewis and Clark Lake (Data Source: Datta et al. 2009)..18

\section{Tables}

Table 1. Emergent Sandbar Habitat Constructed by the Corps on the Missouri River System

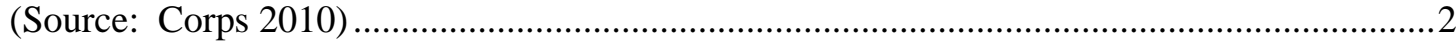

Table 2. Loss of Constructed ESH on the Missouri River..............................................................9

Table 3. Tern and Plover Productivity (fledglings/nest) Among Nesting Habitats of the Missouri River (Source: Corps 2008b) ............................................................................................. 17

Table 4. Proposed Vegetation Removal Treatment Combinations (Source: Corps 2008b)............19 


\subsection{Introduction}

In 1985, the U.S. Fish and Wildlife Service (USFWS) listed the interior population of the least tern (Sterna antillarum) as endangered (50 FR 21784-21792). The piping plover (Charadrius melodus) was also listed as threatened in 1985 (50 FR 50726-50734). The U.S. Army Corps of Engineers (Corps) began consultation with the USFWS in 1989 regarding the operation of the Missouri River Main Stem Reservoir System. The USFWS issued a Biological Opinion (BiOp) in 2000 that concluded actions proposed by the Corps would jeopardize the least tern and piping plover. The $2000 \mathrm{BiOp}$ was amended in December 2003 to include a number of Reasonable and Prudent Alternatives (RPAs). To avoid jeopardy and minimize take of the least tern and piping plover, the Corps would design, construct, and manage new sandbar habitat within the Missouri River System. The Corps would also monitor nesting on this new sandbar habitat to evaluate the effectiveness of habitat creation on the populations of terns and plovers. The Corps would also rehabilitate existing sandbars to benefit the birds (USFWS 2003).

Since the $2000 \mathrm{BiOp}$ and the 2003 amended BiOp, the Corps has implemented research, monitoring and evaluation activities to determine the effectiveness of constructed emergent sandbar habitat. Investigations of tern and plover ecology and their use of emergent sandbars are ongoing, and are intended to provide information about the effects of management actions aimed at maintaining these species. The objective of this document is to provide decision makers with a synthesis of information gathered from 2004 through 2009 regarding the construction and mapping of emergent sandbar habitat, management actions taken, results of tern and plover productivity monitoring, habitat use, and other research activities directed toward use of created and managed habitats.

\subsection{Emergent Sandbar Habitat Construction}

Emergent sandbar habitat (ESH) refers to exposed, inter-channel formations within the river that are often dynamic in nature. In response to goals established by the $2000 \mathrm{BiOp}$ and the $2003 \mathrm{BiOp}$

Amendment, construction of inter-channel ESH began in 2004 and nearly 3 million yards of material has been moved to create about 543 ac of habitat within the Gavins Point Reach and Lewis and Clark Lake (Corps 2010). Each individual sandbar complex constructed by the Corps through 2008 in Gavins Point Reach is presented below and described in chronological order along with a single complex in Lewis and Clark Lake.

- Sandbar Complex 755.0 (Ponca Site). This location was not selected or designated for original ESH construction. The sandbar complex was created by the deposition of spoils into the Missouri River during an adjacent backwater enhancement project about the time the ESH construction program began (Corps 2010). This activity resulted in the construction of three sandbars totaling about 37 ac (Corps 2009; Table 1).

- Sandbar Complex 761.3. In 2004 about 235,000 $\mathrm{yd}^{3}$ of material were redistributed to create about 43 ac of inter-channel sandbar habitat (at a Missouri River discharge of 30 thousand cubic feet per second [kcfs]; Corps 2009).

- Sandbar Complex 770.0. Created in winter of 2005, this complex amounted to 72 ac of habitat at 30 kcfs (Corps 2009). 
Table 1. Emergent Sandbar Habitat Constructed by the Corps on the Missouri River System (Source: Corps 2010)

\begin{tabular}{llcc}
\hline Year & \multicolumn{1}{c}{ Reach } & River Mile & Original Acres \\
\hline 2004 & Gavins Point & 755.0 & 37 \\
2004 & Gavins Point & 761.3 & 43 \\
2005 & Gavins Point & 770.0 & 72 \\
2008 & Gavins Point & 774.0 & 49 \\
2008 & Gavins Point & 775.0 & 44 \\
2008 & Gavins Point & 777.7 & 74 \\
2007 & Gavins Point & 791.5 & 40 \\
2008 & Gavins Point & 795.3 & 77 \\
2007 & Lewis and Clark Lake & 826.6 & 49 \\
2009 & Gavins Point & 781.0 & 40 \\
2009 & Gavins Point & 781.4 & 67 \\
\hline \multicolumn{3}{c}{ Total } \\
\hline
\end{tabular}

- Sandbar Complex 774.0. About 49 ac of ESH were created in November of 2008 by redistributing over 300,000 $\mathrm{yd}^{3}$ of material into 4 sandbars (Corps 2010).

- Sandbar Complex 775.0. Constructed during spring and fall of 2008, this complex was designed to provide 44 ac of ESH using 220,000 $\mathrm{yd}^{3}$ of material (Corps 2009).

- Sandbar Complex 777.7. Seventy-four acres of ESH were completed at this complex in April of 2008 by the redistribution of over 630,000 $\mathrm{yd}^{3}$ of material (Corps 2009).

- Sandbar Complex 791.5. About 40 ac of ESH were created by December 2007 (Corps 2009).

- Sandbar Complex 795.3. A 77-ac ESH complex was created by moving about 250,000 dd $^{3}$ of material by November 2008. Low sandbar elevations in the middle of this complex were submerged in 2009 (Corps 2010).

- Sandbar Complex 826.6. This sandbar complex is the first one created outside the Gavins Point Reach and is located in Lewis and Clark Lake above Gavins Point Dam. Built in 2007, it initially provided 49 ac of new habitat (MRRP 2010).

- Sandbar Complex 781.0. The redistribution of $170,000 \mathrm{yd}^{3}$ of material to create 40 ac of ESH and 10 ac of backwater habitat was finished in November 2009 at this location (Corps 2010).

Immediately following construction, 1- to 2-ft vertical banks were observed along the right bank below the first chute and in two locations on the left bank.

- Sandbar Complex 781.4. This complex was finished in December 2009 and created 20 ac of new ESH by overtopping 67 ac of ESH with about 120,000 $\mathrm{yd}^{3}$ of material (Corps 2010). Further inspection is pending. 


\subsection{Monitoring of ESH}

Mid-channel deposition of material may alter flow patterns, and flow may also alter constructed ESH. To monitor and document these effects, the Corps conducts annual monitoring (i.e. Pedestrian Surveys) in the vicinity of all constructed ESH complexes. The Corps also conducts biological monitoring of constructed ESH to determine its use by nesting least terns and piping plovers. Results of these monitoring programs are summarized here along with habitat delineation efforts conducted and funded by the Corps within the Missouri River Recovery Program. The Missouri River Recovery Program, administered by the Corps and the U.S. Fish and Wildlife Service, manages activities to restore ecological function to the Missouri River.

\subsection{Physical Monitoring}

\subsubsection{Pedestrian Surveys}

The Corps gathers reconnaissance-level field data to monitor bank erosion, sandbar erosion, succession, and flow patterns in the vicinity of constructed ESH as well as changes in ESH slope and areal extent. Remotely sensed data (Quickbird photography) are also used to monitor bank erosion. The results of this monitoring are presented for each individual constructed sandbar complex below.

- Sandbar Complex 755.0 (Ponca Site). This complex began as three sandbars totaling about 37 ac in 2004. Erosion eliminated the middle and downstream sandbars and reduced the area of the upstream sandbar to 3.2 ac by the end of 2009 (Figure 1). Erosion has also created a vertical bank along the entire western side and the downstream end of the eastern side of the remaining sandbar. Vegetation never became fully established on this complex (Corps 2010).

As stated in the previous section, this complex was not originally designated as an ESH construction site and was opportunistically created as a result of nearby dredging work. The result was the construction of a complex that didn't withstand erosion and was mostly gone within 5 years.

- Sandbar Complex 761.3. Although eroded, most of this complex is still present and amounted to almost 35 ac in 2009 (Figure 2). Most erosion was during the first year, with very little occurring since 2005 (Corps 2010). Vegetation has become established on lower elevations of this complex. Higher elevation areas remain mainly vegetation free. However, monitoring indicated 1 to 3 vertical feet of elevation have been lost, possibly from wind and water erosion or settling, and plants are becoming more numerous.

- Sandbar Complex 770.0. Created in winter of 2005, this complex amounted to 72 ac of habitat at 30 kcfs. Wind erosion, settling, and erosion of the northern side were compounded when significant erosion occurred the following winter when the river iced over resulting in substantial loss of ESH acreage (Corps 2008a). Cottonwoods became sparsely distributed. Very little bank line erosion can be attributed to construction here. A significant amount of accretion that has occurred on the Nebraska side of the river now appears to be eroding (Corps 2010).

- Sandbar Complex 774.0. Erosion has created a 2- to 3-ft vertical bank along the Nebraska side of this complex and part of the upstream end; most of the South Dakota side of the complex has abundant shallow sloping banks. Approximately 7\% of this complex was lost to erosion in the first year (Corps 2010). 
- Sandbar Complex 775.0. Erosion was immediately noted following construction by the presence of a 2- to 4-ft cut bank at the upstream edge and a 1-ft cut bank along the downstream sandbar. The upstream cut bank appeared a foot lower in 2009 (Corps 2010).

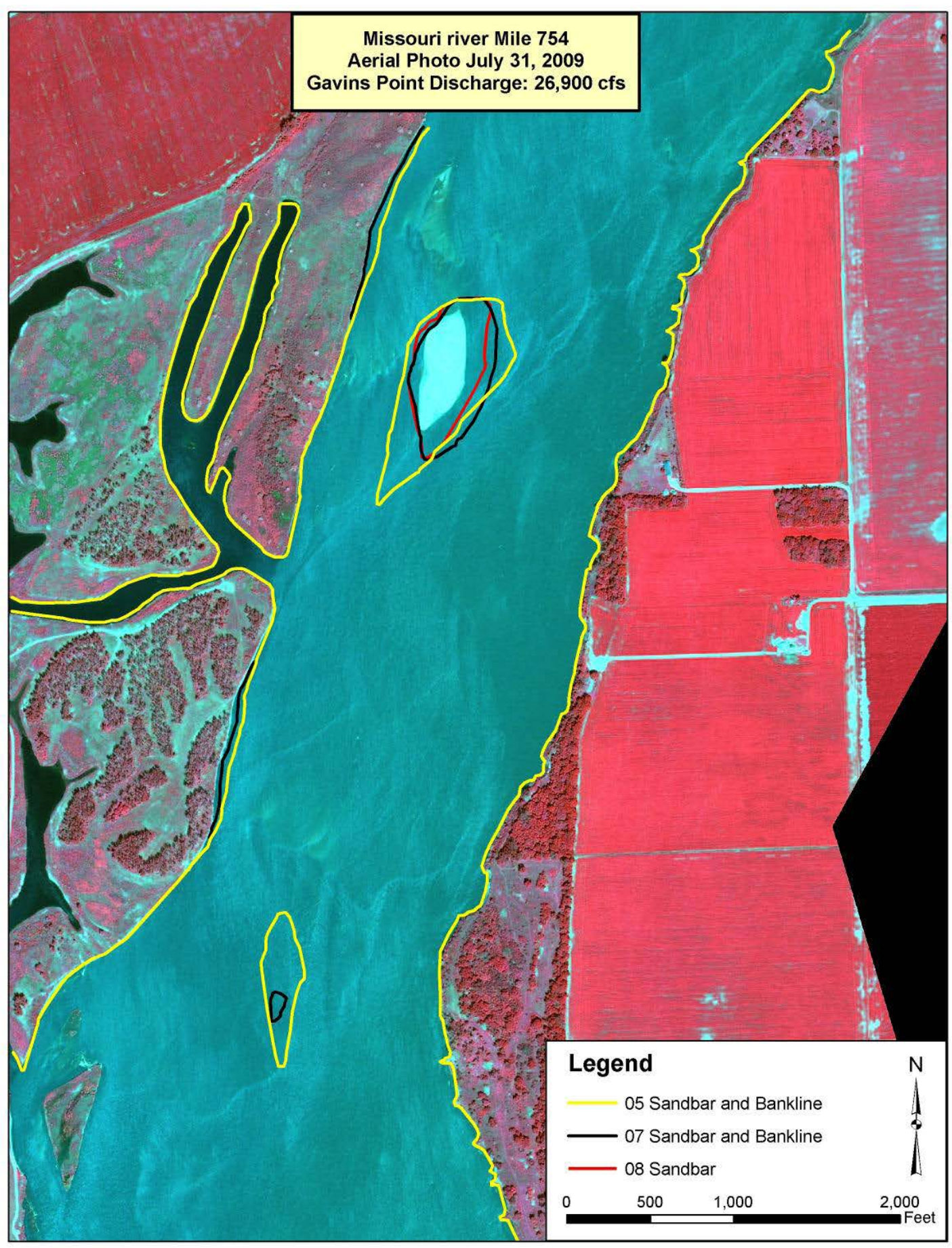

Figure 1. Quickbird Image of Site 755.0, Ponca Complex Showing an Example of the Aerial Extent of Erosion Since Construction (Source: Corps 2010) 


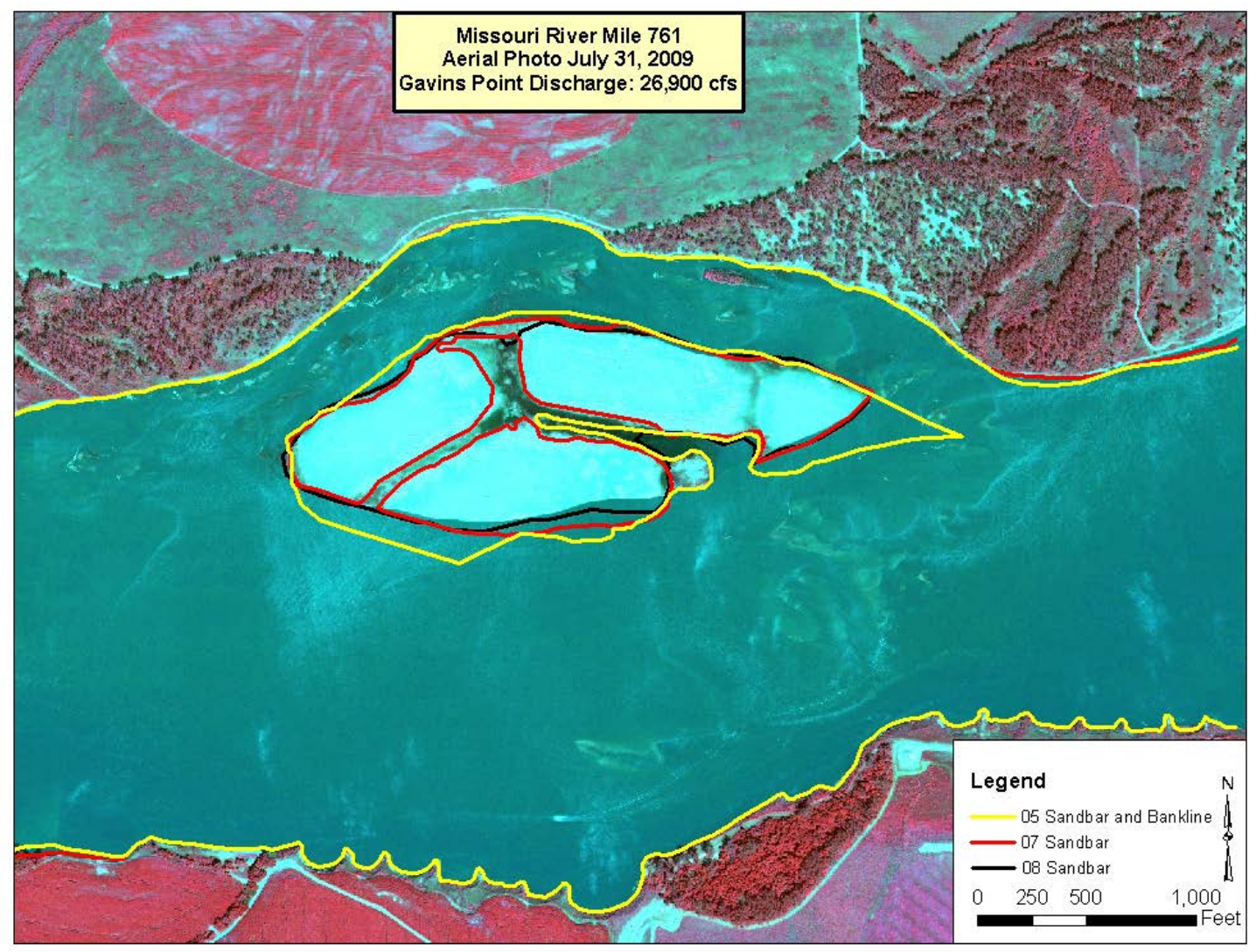

Figure 2. Quickbird Image of Site 761.3 Showing an Example of the Aerial Extent of Erosion Since Construction (Source: Corps 2010)

- Sandbar Complex 777.7. During the summer following construction, a 1- to 2-ft cut bank formed at the head of the complex (Corps 2009). Also noted one-third of the way down from the head was a cut bank that ranged from $0 \mathrm{ft}$ to $4 \mathrm{ft}$ in height that persisted through 2009 (Corps 2010). Vegetation is sparse on the approximately 60 ac that still remained during 2009, except on the old bar that is very distinguishable from the rest of the complex by the presence of vegetation.

- Sandbar Complex 791.5. By 2008 a 1- to 2-ft cut bank formed along the length of sandbar on the southwest side and a 2- to 3-ft cut bank formed about half way down the north side (Corps 2009). Vegetation was sparse to nonexistent in 2008 and was sparse in 2009 (Corps 2010). The surface had a thin layer of substrate larger than what was observed on other constructed ESH that was probably exposed by severe wind erosion. Gentle slopes could be found at the upper and lower ends and adjacent to the chute, but were steep elsewhere. By 2009, erosion narrowed the complex and reduced the acreage to just under 33 ac. Bank-line erosion has been noted nearby resulting in trees falling into the river.

- Sandbar Complex 795.3. Vegetation was sparse in 2009, and cut banks 1- to 4-ft high were noted at various locations on the upstream and downstream bars. Bank-line erosion has been observed on the right bank where riprap is not present, while the left bank (South Dakota side) has accreted (Corps 2010). 
- Sandbar Complexes 826.6, 781.0, and 781.4. No pedestrian survey information was available for this complex.

\subsubsection{Sandbar Habitat Delineation}

From 1996 through 2000 the Corps conducted an effort to delineate least tern and piping plover nesting habitat within the Gavins Point Reach using high-resolution digital aerial orthophotos in conjunction with nest monitoring efforts. The goals of this effort were to identify landscape-level features, and to define and determine the extent and distribution of nesting and foraging habitat (Vander Lee 2002). Potentially suitable areas were classified into six categories: water, submerged sand, wet sand, dry sand, live vegetation, and residual vegetation.

Following the 1997 flood event, the amount of available sandbar habitat tripled. The amount of bare sand increased almost six-fold, and previously vegetated areas experienced a 50\% reduction in plant cover. By 2000, sandbar habitat covered in vegetation had tripled and erosion reclaimed over 1100 ac resulting in a $60 \%$ decrease in ESH. It was noted that both plovers and terns preferred the largest sandbars with the greatest amount of bare sand.

In 2005, another study was begun to explore the cost-effectiveness of using different types of remotely sensed data to estimate habitat quantity (Sherfy et al. 2008). Color infrared aerial photography was acquired during June 2007 for each of four Missouri River reaches. QuickBird satellite imagery was also acquired during mid-June to mid-July, September, and mid-October to mid-November in 2007. Light Detection and Ranging (LIDAR) elevation data were acquired during November. QuickBird Imagery was also acquired in 2008 for the four Missouri River reaches. Unlike 2007, image acquisition occurred whenever the satellites passed over the study area beginning in May and ending September through December depending on the reach. This provided five, six, or seven images of each reach (Sherfy et al. 2008).

These products were used to develop a process to efficiently create land cover maps and accurately assess least tern and piping plover habitat quality and quantity (described in detail below). The U.S. Geological Survey (USGS) continues to develop a semi-automated process to inventory and map land cover along the Missouri River using multiple data sources through time. The timing of data acquisition has implications on the similarity of information, and variation among data sets from differences in solar zenith angle and atmospheric conditions can be considerable. Processes to standardize the information and limit the effects of this variability were developed in 2008 (Sherfy et al. 2009a).

\subsubsection{Gavins Point Reach}

A habitat map was created from the aerial photography, and an accuracy assessment was completed in 2007. A two-tiered approach was used in classifying habitats. The upper tier has four classes: water, island, floodplain, and terrace and valley wall. Floodplain is defined as the active floodplain and includes areas regularly inundated. The terrace and valley wall class includes higher-elevation areas adjacent to the river and to the edges of valleys, including the valley edge (Sherfy et al. 2009a). The lower tier originally had 7 classes, but was later revised to 15. Four classes, found on islands and in the floodplain, provide habitat for least terns and piping plovers: dry sand, dry sand sparse vegetation, wet sand, and wet 
substrate sparse vegetation. A fifth class, a transition between open ground and vegetation, was also mapped as well as 10 additional vegetated land cover classes not typically used by terns or plovers. Analysis of LIDAR data for the Gavins Point Reach was completed by 2007, resulting in a bare-earth elevation model, vegetation-height model, and a slope model (Sherfy et al. 2008). A new method of defining the high bank line to identify sandbar habitat that is attached to the floodplain was also developed in 2007.

Habitat was also classified based on both the aerial photography and from the QuickBird satellite imagery obtained prior to 2008. Habitat attributes were assessed on the ground at designated sample points to determine the actual habitat class (ground truthing). These ground observations were compared to predicted conditions based on both aerial imagery and the QuickBird satellite imagery. Classification of the four tern/plover habitat classes (dry sand, dry sand sparse vegetation, wet sand, wet substrate sparse vegetation) works well (Sherfy et al. 2009a), although wet sand was the most difficult to predict, which may indicate the prevalence of this habitat is highly variable and dependent on flow. The amount of nesting habitat was calculated by summing the areas of dry sand, dry sand with sparse vegetation, and wet sand land cover classes on both islands and shoreline sandbars for 2005 through 2007 (Sherfy et al. 2009a). Acreage ranged from 1026 at about 24 kcfs in 2006 to 1195 at about 22 kcfs in 2007. The USGS used the frequency with which nests occur within predicted habitat types recognized as suitable for nesting as an independent indicator of accuracy. By overlaying nest location on predicted habitat type, the USGS found 98\% of year 2007 nests occurred within habitat predicted to be suitable for nesting even though these habitats occupy only $6.6 \%$ of the landscape (Sherfy et al. 2008). Summarizing across years 2005 through 2007, about 95\% of nests were located in sand habitats that occupied 18\% of the land area (Sherfy et al. 2009a).

The USGS also attempted to estimate the amount of sparse vegetation using the QuickBird satellite imagery. Imagery was acquired during May, early July, and mid-July of 2007, while vegetation was measured during early July. Statistical analyses indicated the satellite imagery could be used to estimate relative amounts of vegetation in sparsely vegetated areas, although the imagery did not function well at some locations due to differences in vegetation structure (Sherfy et al. 2008).

The USGS has also created a simple sandbar inundation model for the Gavins Point Reach. This model uses gauging station stage data to model the water-surface elevation. The bare-earth elevation created from LIDAR data is then subtracted from the predicted water-surface elevation to create a "relative elevation model" which predicts the land-surface elevation relative to the water-surface elevation (Sherfy et al. 2008). Evaluation of the inundation model was accomplished by comparing a map of inundated/not inundated lands from the land-cover model developed from the QuickBird imagery with a water/land map created at the discharge levels of the time the imagery was acquired from the LIDAR data. Thirteen predictions were tested with respect to location and date. Accuracy ranged from $70 \%$ to $98.2 \%$ with 11 prediction values over $90 \%$. Factors that contributed to prediction errors appear to be elapsed time between LIDAR and QuickBird acquisition, channel complexity, and river discharge. The prediction with the lowest accuracy, which was the Missouri River between the James and Vermillion Rivers in October 2007, was likely affected by the timing of image acquisition and stagerelated gauging station inaccuracies. Recently constructed ESH was also a source of error if it occurred after data acquisition (Sherfy et al. 2009a).

The USGS concluded change in low elevation sandbars over time may account for more model error than measurement errors, because the dynamic processes of the river act quickly enough to change the 
size and distribution of sandbars between the acquisition dates of remotely sensed data (Sherfy et al. 2009a).

\subsubsection{Fort Randall Reach}

The USGS attempted analysis of LIDAR data for the Fort Randall Reach, but missing data did not allow completion (Sherfy et al. 2008).

\subsubsection{Lake Sakakawea}

Most nesting habitat provided at Lake Sakakawea is not actually ESH, but is shorelines exposed by low water levels in the reservoir. This information is provided in this document because it pertains to both plover and tern management within the Missouri River system.

Delineation of habitat at Lake Sakakawea presents different issues than other Missouri River reaches. The immensity and diversity of shoreline habitat along Sakakawea precludes the use of data-intensive approaches used elsewhere. To begin to map suitable nesting habitat, USGS delineated the shoreline and islands into 2-km segments using 2004 aerial color imagery (Sherfy et al. 2008). The USGS is gathering data to design a model to predict the amount of habitat availability. However, it appears that the characteristics of habitat used by nesting plovers are different than other river reaches, vegetation dynamics and succession act differently, and the digital elevation model developed from topographic data collected before the basin was flooded is outdated (Sherfy et al. 2009a).

\subsubsection{Other Missouri River Reaches and Lakes}

Information on nesting habitat delineation at other locations along the Missouri River System was not available at the time of this document.

\subsubsection{Summary of Physical Monitoring}

Wind and water erosion as well as accretion continue to act on constructed $\mathrm{ESH}$, generally reducing the acreage, lowering the elevation, and forming vertical cut banks along portions of many sandbars. By 2009, approximately 39\% of the originally constructed ESH acreage habitat had been lost to erosion (Table 2). However, most of the erosion loss had occurred at two complexes under unique circumstances and only $21 \%$ of all of the other constructed ESH acreage was lost to erosion by 2009. Erosion from river flow has also formed cut banks along one side of most constructed sandbars, potentially reducing the foraging area for young plovers (Corps 2010). Lowering of elevation from wind erosion and settling may also reduce acreage depending on the sandbar design and flow regime. The risk of nest loss from inundation may also increase because the relative elevation of nests could be reduced.

Succession, or establishment of vegetation, also continues to affect constructed ESH. Plovers and terns select nest sites with little or no vegetation. Constructed ESH appears to generally function well as tern and plover nesting habitat for 2 years following construction. Vegetation management actions, which 
have been successful at reducing vegetation and attracting nesting terns and plovers, may then be warranted to extend the viability of constructed ESH as nesting habitat.

Table 2. Loss of Constructed ESH on the Missouri River

\begin{tabular}{ccccc}
\hline Construction Year & Original Acres & 2009 Acres & Acres Lost & \% Decline \\
\hline 2004 & 37 & 3.2 & -33.8 & 91 \\
2004 & 43 & 34.9 & -8.1 & 19 \\
2005 & 72 & 2 & -70 & 97 \\
2007 & 40 & 32.6 & -7.4 & 19 \\
2008 & 49 & 45.6 & -3.4 & 7 \\
2008 & 44 & 25.5 & -8.5 & 42 \\
2008 & 74 & 60.1 & -3.9 & 19 \\
2008 & 77 & 60 & -7 & 22 \\
2008 & 40 & - & - & - \\
2009 & 67 & - & - & - \\
2009 & 49 & - & - & - \\
\hline Total & $\mathbf{5 4 3}$ & $\mathbf{2 6 3 . 9 ^ { ( \mathbf { a } ) }}$ & $\mathbf{- 7 2 . 1}^{\text {(a) }}$ & $\mathbf{3 9}^{\text {(a) }}$ \\
\hline
\end{tabular}

(a) Calculated from 436 ac constructed within the Gavins Point reach only.

The Corps began habitat delineation efforts in 1996 and documented creation and subsequent succession of ESH through the 1997 flood. In 2005, the USGS developed methods to efficiently create land-cover maps and accurately assess tern and plover habitat at the landscape scale. Color infrared aerial photography, QuickBird satellite imagery, and LIDAR elevation data were ground-truthed with field data to produce a habitat map and an acreage estimate of available habitat within the Gavins Point reach. A full data set was not available for the Fort Randall Reach, and habitat differences and preferences along Lake Sakakawea limited use of the approach developed for the Gavins Point reach.

\subsection{Biological Monitoring}

\subsubsection{Habitat Monitoring}

In 2009, the Corps characterized piping plover and least tern habitat use on constructed ESH in Gavins Point Reach and Lewis and Clark Lake from 4 years of field study (Huber et al. 2009). The objectives of this research were to characterize nesting habitat and compare to unused but apparently suitable habitat. Habitat information was gathered at 403 plover and 534 tern nests as well as 2010 random locations. Plovers preferred nesting in gravel and pebble substrates with some woody vegetation and avoided areas of herbaceous vegetation and leaf litter. Terns also preferred gravel and pebble substrates and avoided herbaceous vegetation and leaf litter. Terns also located nests in areas with small and large debris and avoided silt substrates. Habitat characterization during the study indicated that constructed habitats initially functioned well as nesting habitat for both plovers and terns. However, as time passed natural processes including erosion and succession lessened the quality of constructed habitats for nesting habitat. 


\subsubsection{Productivity and Population Monitoring}

From 1991 through 2001, the Missouri River System had become an increasingly important producer of piping plovers in the Prairie Canada/U.S. Northern Great Plains population (Haig et al. 2005). Productivity monitoring data from the entire Missouri River System indicates that generally the number of piping plovers fledged is highly variable, ranging from 359 in 2001 to 1179 in 2004. The regional importance of various reaches is also variable and changes over time (Figure 3). Lake Sakakawea, the Gavins Point Reach, Lake Oahe, and the Garrison Reach produced over 90\% of the piping plovers along the Missouri River from 2000 through 2009, although Lewis and Clark Lake has recently become a major contributor of fledged plovers regionally. As late as 2004, plovers nesting within Lake Sakakawea habitats fledged nearly half of all young produced (552 of 1179), yet in 2009 only nine plovers were fledged there.

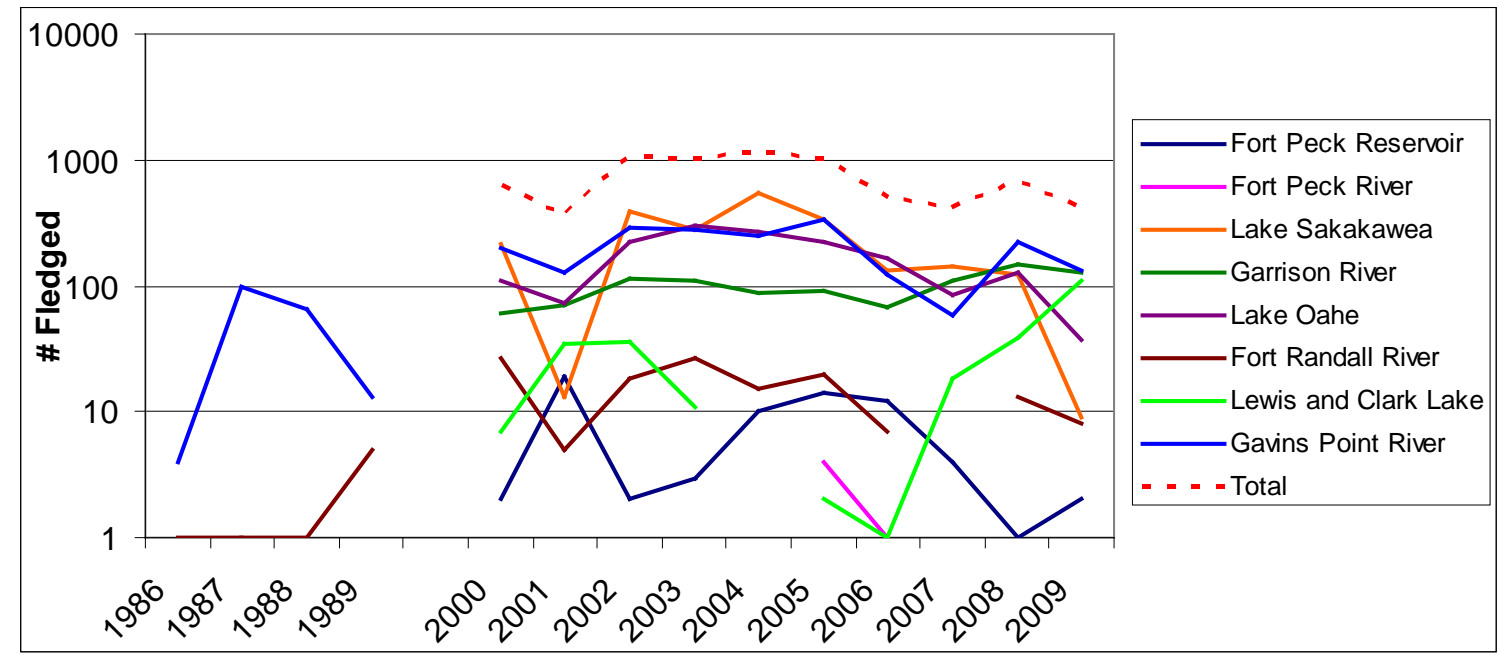

Figure 3. Sum of Piping Plover Fledglings Within Various Reaches of the Missouri River System, 1986-1989 and 2000-2009 (Data Sources: Corps DMS Database and USFWS 1990a)

Least tern productivity along the Missouri River has also been variable, although less so than piping plovers. Total production has ranged from 300 to 500 fledglings annually since 2000 (Figure 4). As for piping plover production, the Gavins Point Reach, Lake Oahe, and the Garrison Reach were major tern production areas, accounting for over $77 \%$ of total fledglings along the Missouri River. However, unlike plovers, Lake Sakakawea is not a big producer of least terns - annual production was under 20 fledglings. 


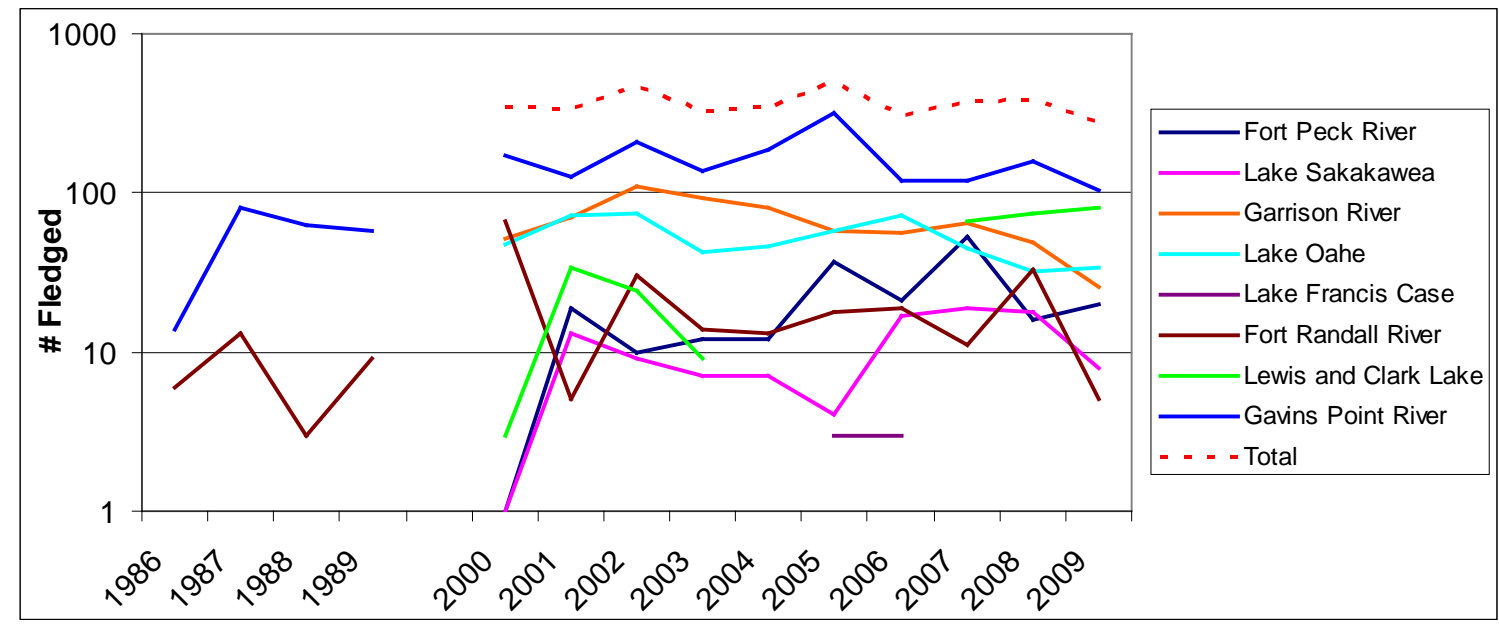

Figure 4. Sum of Least Tern Fledglings Within Various Reaches of the Missouri River System, 19861989 and 2000-2009 (Data Sources: Corps DMS Database and USFWS 1990a)

\subsection{Focused Research}

The Omaha Corps has contracted several entities to conduct research related to and monitoring of constructed ESH on the Missouri River, including the USGS and Virginia Polytechnic Institute (VPI). This section summarizes efforts and results to date by these organizations.

\subsection{Piping Plover Use of Constructed ESH}

\subsubsection{Nesting Ecology}

From 2005 through 2009, VPI studied the suitability of constructed ESH for nesting piping plovers. Sandbar complexes below Gavins Point Dam were surveyed for piping plovers (Catlin and Fraser 2010a). Sandbars constructed within Lewis and Clark Lake were later included in this study (Catlin and Fraser 2010c; Felio et al. 2010b). Each sandbar that provided suitable nesting habitat was surveyed twice at the beginning of the field season. Sixteen sandbars (12 natural, 4 engineered) were then selected for further population monitoring based on plover occupancy as well as sandbar size, location, and origin (natural, constructed, or modified). Selection was done at varying levels of each attribute to accurately represent available habitat throughout the reach, represented various levels of habitat management effort (construction, vegetation control), and included all constructed sandbars. Nest searches and monitoring continued during 2005 after adult surveys were complete. Each discovered nest was mapped and monitored every 2 to 3 days to determine its fate. Following hatching, brood monitoring was initiated to track the fate of broods. In 2006, only the 16 sandbars that were studied during 2005 were surveyed for adults (Catlin and Fraser 2010b), and in 2007 three additional sites where new sandbars were planned for the following year were also surveyed (Catlin 2009). Although the difference in effort precludes direct comparison of adult counts among years, nest counts on the 16 sandbars indicated a consistent nesting effort of a slightly more than 200 plover nests/year. More plovers nested on constructed sandbars than natural sandbars regardless of whether vegetation had been manipulated (Figure 5), because almost 55\% of nests recorded on the selected sandbars occurred on constructed habitats. In addition, in 2006 and 
2007 plovers nested on engineered sandbars at rates greater than would be expected, indicating that plovers preferred engineered over natural habitats (Catlin 2009).

In 2008 and 2009, over 47\% of plover nests either hatched or were likely to have fledged at least one chick (Felio et al. 2010a; 2010b). Nest exclosures were used on Gavins Point to limit nest predation. Monitoring indicated nest exclosures had a positive but statistically insignificant effect on the daily survival rate (DSR) of plover nests from 2005 through 2007 (Catlin 2009). However, indication of adult predation by great horned owls and/or mink may limit the overall effectiveness of the exclosures.

Research was conducted to evaluate the effectiveness of predator removal in the vicinity of constructed sandbars, but results were not publicly available at the time of this report.

VPI located and monitored piping plover nests on 16 sandbars within the Gavins Point Reach (Catlin and Fraser 2010a) and 1 or 2 constructed sandbars in Lewis and Clark Lake. Nest substrate was recorded at 620 piping plover nests. Dry sand was the most often recorded nesting substrate, accounting for nearly 88\% of recorded nests (Figure 6). Fifty-six plover nests (9\%) were found on moist sand, and other substrates each contained less than $1 \%$ of the recorded plover nests.

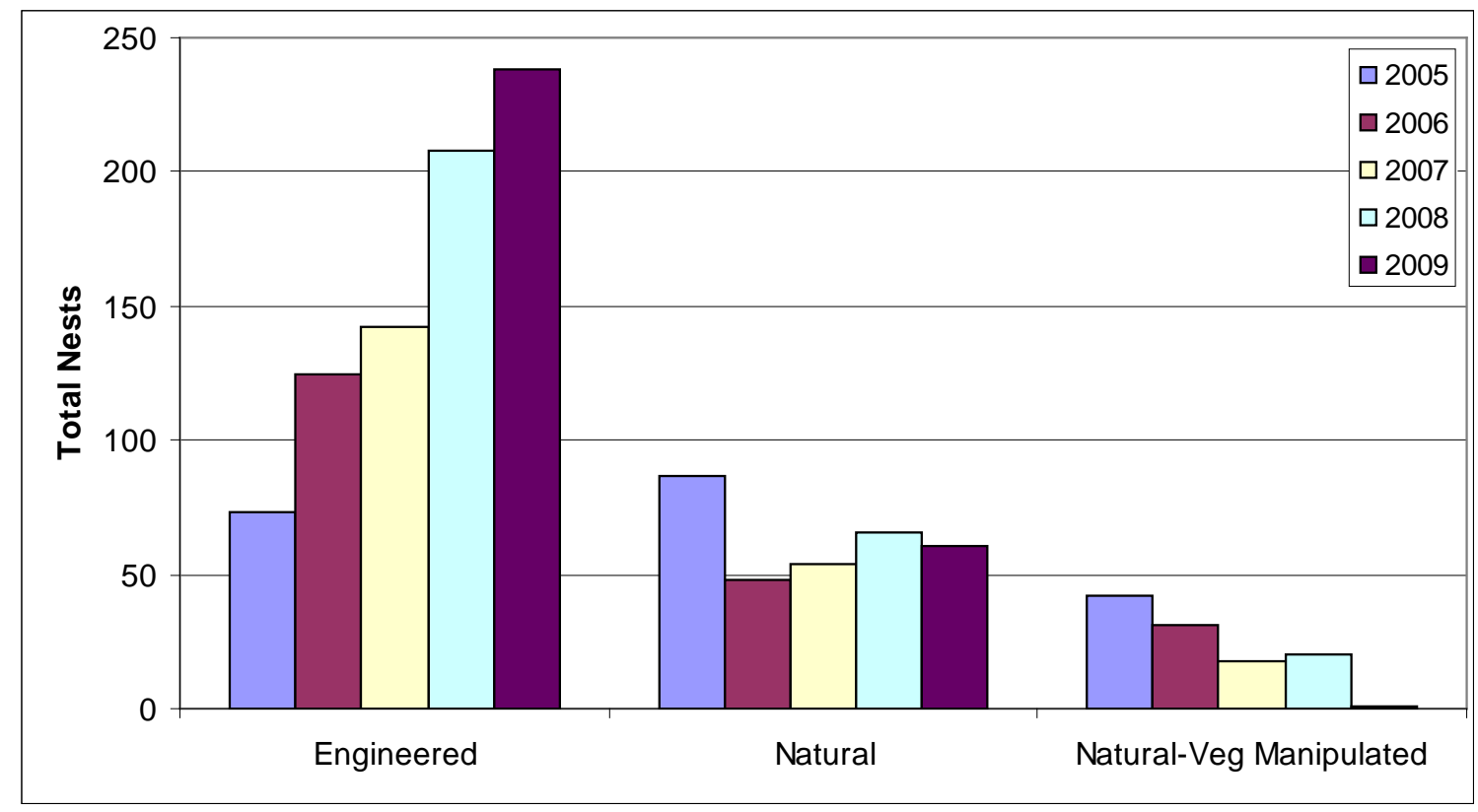

Figure 5. Piping Plover Use of Nesting Habitat on Monitored Sandbars Within the Gavins Point Reach and Lewis and Clark Lake from 2005 Through 2009 (Sources: Catlin and Fraser 2010a, 2010b, 2010c; Felio et al. 2010a, 2010b) 


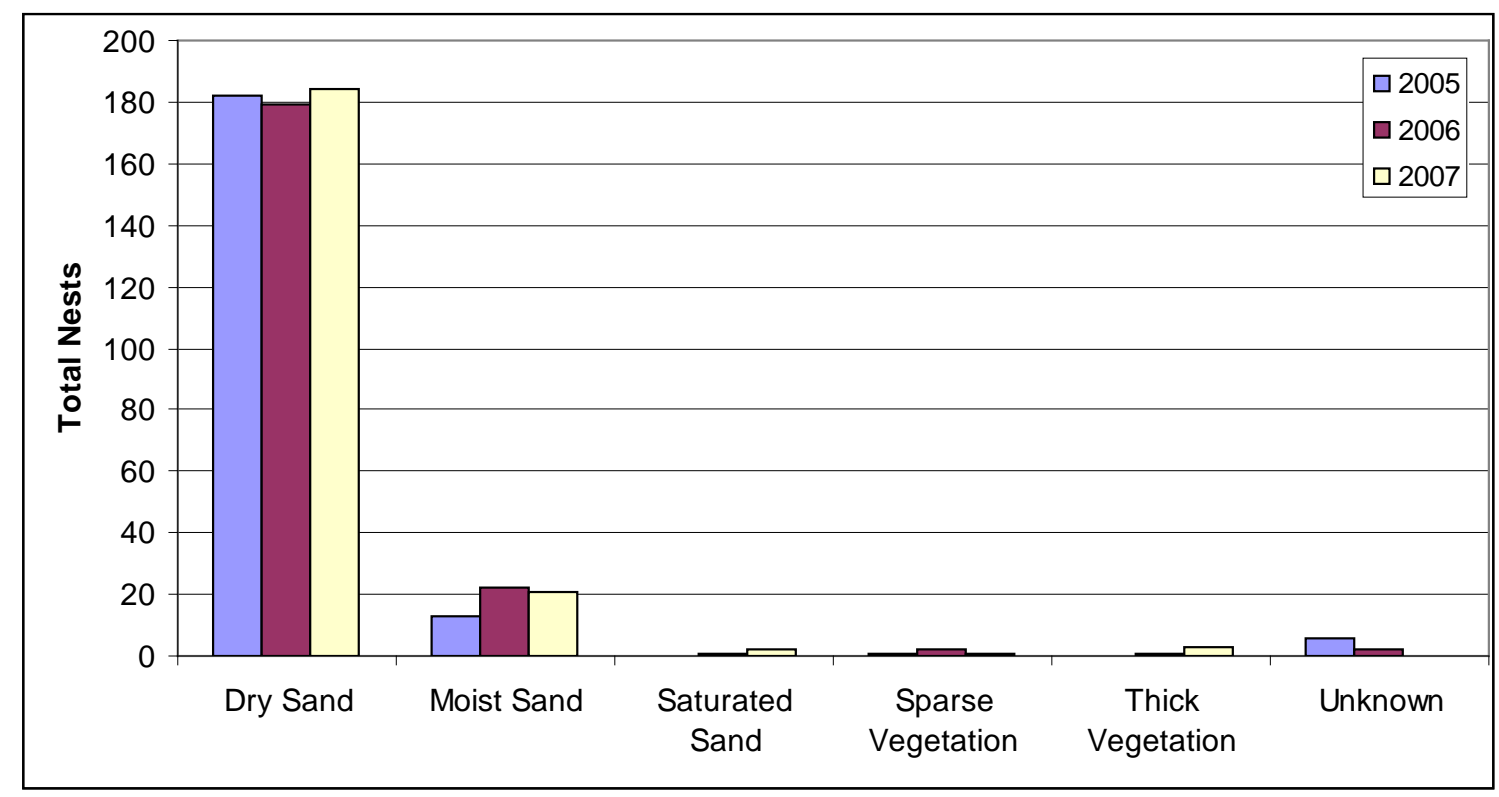

Figure 6. Piping Plover Use of Nesting Substrates on Monitored Sandbars Within the Gavins Point Reach and Lewis and Clark Lake from 2005 Through 2007 (Sources: Catlin and Fraser 2010a, 2010b, 2010c)

The USGS measured least tern and piping plover nesting habitat characteristics at several spatial and temporal scales from 2006 through 2009 within the Gavins Point and Garrison reaches as well as Lewis and Clark Lake (Sherfy et al. 2008, 2009a, 2009b). Data were recorded at all nest sites at the time of nest discovery. Additional data were recorded in the vicinity of the nest at $3 \mathrm{~m}, 10 \mathrm{~m}$, and $500 \mathrm{~m}$ from the nest. At Lake Sakakawea, available habitat was also characterized along thirty 2-km segments using transects spaced every $100 \mathrm{~m}$. These efforts resulted in habitat measurements at 1284 least tern nests and 1308 piping plover nests. However, results or data have not been made publicly available at the time of this report.

\subsubsection{Survival}

Catlin (2009) also calculated the DSR for piping plover nests on selected sandbars in the Gavins Point Reach and upper portion of Lewis and Clark Lake from 2005 through 2007. The DSR remained stable, but nests on constructed habitats experienced a 2.5-fold higher DSR than nests occurring on natural sandbars. Juvenile piping plover survival from one breeding season to the next was also modeled on 16 sandbars (12 natural, 4 constructed) in the Gavins Point Reach and Lewis and Clark Lake from 2005 through 2007. Apparent juvenile survival increased with increased nest density on natural sandbars, and decreased with increased density on constructed sandbars (Catlin 2009). From 2005 through 2006, the apparent survival rate was about the same $(\sim 0.55)$ on all sandbars that had about one nest per hectare. However, as density increased to 2.5 nests/ha, natural sandbar apparent survival rate increased to about 0.85 while the apparent survival rate declined to about 0.3 on constructed sandbars. From 2006 through 2007, plover apparent survival rate was noticeably lower on natural sandbars, being 0.2 at 0.5 nests/ha and increasing to 0.45 at 1.5 nests/ha. Like the previous year, apparent survival rates increased with increased density on natural sandbars and decreased with increased density on constructed sandbars (Catlin 2009). Apparent survival rates on constructed sandbars were about 0.43 at the lowest density of 
1.5 nests/ha dropping to about 0.11 when nests were $4 /$ ha. However, density of nesting pairs on the natural sandbars ranged from 0.5 to $1.5 /$ ha while on constructed sandbars was 1.5-4.0 pairs per hectare.

Survival of plover adults and fledglings from the end of a nesting season to the beginning of the next is influenced by many factors, including food availability, predation, disease, weather, and habitat quality and quantity along migration routes and wintering grounds. Estimates of survival are derived from the marking and resighting of plover adults and chicks. When modeling survival using mark/relocation techniques, apparent survival represents a minimum estimation of true survival because the number of individuals that actually survive but do not return to be counted (emigration) is not easily assessed (Sandercock 2006). Survival estimates calculated by Catlin (2009) were similar to previous estimates (Larson et al. 2000). Catlin (2009) observed the highest plover emigration rates after a year of higher water that resulted in increased nest density and decreased reproductive success. The fact that the DSR of plover chicks on constructed sandbars was more than double what was observed on natural sandbars, yet apparent survival decreased with increasing nest density on constructed sandbars may simply indicate an emigration tendency among plover chicks raised on sandbars with many other plover chicks.

Additionally, high permanent emigration rates have been acknowledged among young shorebirds and Great Plains piping plovers in particular (Larson et al. 2000). The site fidelity rate of banded adults was high (>0.9). Site fidelity rates were lower among chicks, and interestingly were lowest among chicks banded and reared and on natural sandbars (0.75-0.5 engineered vs. 0.4-0.2 natural).

Adult plover survival was also modeled on 16 selected sandbars (12 natural, 4 engineered) in the Gavins Point Reach and Lewis and Clark Lake (Catlin 2009). The apparent survival rate on the Missouri River from 2005 through 2007 was about 0.82 and did not differ among natural and engineered sandbars. Apparent survival rates observed also compared favorably to survival rates observed elsewhere (Catlin 2009).

\subsubsection{Foraging Ecology}

When piping plovers choose a nest site, they must often evaluate the foraging potential of the vicinity because early-in-life young birds are dependent upon foraging habitat to which they can walk. Piping plover adults and chicks feed exclusively on invertebrates in mostly open habitats. Research was conducted to characterize plover use of sandbar habitats while foraging. Adult plover use of protected vs. exposed shorelines was recorded, and plover chick use of the following four habitats was also recorded: saturated, moist, dry, and vegetated (Le Fer et al. 2008). Saturated habitats were adjacent to the water's edge and retained a wet sheen. Soil in moist habitats appeared darkened by moisture but was not saturated. Dry sand is found at slightly higher elevations, and was classified as vegetated if it had $\geq 10 \%$ plant cover.

Although adult piping plovers occurred on both protected and exposed shorelines, about $92 \%$ of foraging adults were observed on protected shoreline even though this shoreline only constituted about $58 \%$ of available shoreline. Piping plover chicks were observed foraging in all habitats. However, chicks foraged in saturated and moist habitats more than dry and vegetated habitats within the Gavins Point and Garrison reaches, but didn't appear to be selective of foraging habitats at Lake Sakakawea (Le Fer et al. 2008).

Generally, invertebrate abundance and biomass did not accurately predict plover habitat use. For instance, insects were more plentiful in vegetated than saturated substrate in the Garrison Reach even 
though chicks spent more time in saturated and moist substrates. Secondly, although adult plovers preferred to forage along protected shorelines, captured insect numbers and biomass were not always highest along these shorelines. This may indicate that plovers may not necessarily select foraging habitat for prey availability alone. Habitat use indicates that saturated and moist areas are important for plover chick foraging, and protected shorelines are important to foraging adults.

\subsection{Least Tern Use of Constructed ESH}

\subsubsection{Nesting Ecology}

The USGS monitored least tern nests and measured habitat characteristics at several spatial and temporal scales from 2006 through 2009 within the Gavins Point and Garrison reaches as well as Lewis and Clark Lake (Sherfy et al. 2008, 2009a, 2009b). Data were recorded at all nest sites at the time of nest discovery. Sherfy et al. (2010) measured habitat at 798 tern nests as well as 1113 random points on both constructed and natural sandbars within Gavins Point and Lake Sakakawea. Most (699) nests and random points (849) occurred on constructed sandbars. Fifteen variables were recorded, describing substrate and vegetation. The results indicated that least terns generally preferred nest sites with coarse substrates and avoided places with vegetation, leaf litter, and silt substrates. These results were similar to previous studies, but were observed at a finer scale during this study, indicating selection for these habitat attributes may occur at multiple scales. Several differences were observed between constructed and natural sandbars because terns were much more selective on constructed habitats. On constructed sandbars, terns avoided terrestrial vegetation and pebble substrate and were attracted to debris and gravel substrate. These trends were not observed on natural sandbars. Woody vegetation was more prevalent on natural sandbars, while gravel was more abundant on constructed sandbars.

Although constructed habitats appeared structurally simple, terns appeared to select nest site location based on subtle variations in substrate, vegetation, and debris. Terns nest site selection is likely influenced by other factors not measured in this study, because they are colonial and may benefit from selecting a location among other nests. Tern avoidance of silt substrate and vegetation on constructed sandbars was stronger than their attraction to the other variables, indicating management actions targeting these variables may be more effective. However, it is not known how fine-scale habitat selection is related to nest success and productivity. Overall, terns showed considerable variation in fine-scale nest site selection between natural and constructed sandbars and it is unclear how management actions designed to reproduce conditions preferred on constructed sandbars would affect the tern population. Additional nest site selection data gathered at Garrison and Lewis and Clark Lake were not publicly available at the time of this writing.

\subsubsection{Forage Fish Distribution}

To characterize shallow water prey fish communities associated with natural and constructed ESH habitats, the USGS assessed fish species composition, relative abundance, species richness, and size within Gavins Point Reach and the delta-lake transition of Lewis and Clark Lake (Stucker et al. 2010). From 2006 through 2008 fish were sampled during the June-August tern breeding season about 0.5 river mile(s) (rm) from constructed sandbars and natural sandbars that contained tern nests within the previous

5 years. Site attributes, including depth, turbidity, temperature, and substrate were also recorded. A total of 10,015 fish of 35 species were captured in 230 samples. Bigmouth buffalo (Ictiobus cyprinellus), 
emerald shiner (Notropis atherinoides), sand shiner (N. stramineus), and spotfin shiner (Cyprinella spiloptera) were the four most common species and combined accounted for $60 \%$ of all fish captured. Variability in fish communities was related to physical habitat characteristics rather than to ESH type, because fish abundance, species richness, and size class were not different between natural and constructed ESH habitats. Fish were more abundant in shallower water, indicating shallow-water habitats such as channel edges and sandbar margins are important tern foraging areas.

\subsection{Vegetation Management}

In 1987, the Corps initiated vegetation control and mechanical habitat manipulation methods as a means to gain information in preparation for the issuance and implementation of a USFWS BiOp. Initial efforts, conducted in the Gavins Point Reach and downstream from Fort Randall Dam from 1987 through 1992, included tilling, disking, mowing, burning, pulling, herbicide treatment (Rodeo, Norosac 10-G), and burning or mechanical removal of dead vegetation (Latka et al. 1993). Several vegetationmanagement methods were successful at removing and controlling vegetation. Application of a preemergent herbicide coupled with tilling or disking limited vegetation and resulted in both tern and plover nesting, while tilling or disking alone resulted in dense annual vegetation growth. Hand-clearing also reduced vegetation and subsequent use by terns and plovers. Island build-up experiments were also conducted and included fencing followed by oyster shell deposition as well as use of heavy machinery. Fencing resulted in deposition behind the fence, but wind erosion eliminated deposited sand unless the sand surface was treated (oyster shells). Following these efforts the Corps systematically studied the use of Arsenal, a pre-emergent and post-emergent herbicide, on controlling vegetation on a single sandbar in Lewis and Clark Lake that had previously supported plover nests. Arsenal and a combination of Arsenal and mowing eliminated woody vegetation and forb cover 6 weeks after treatment but standing dead vegetation in spray-only treatments still contained residual plant cover (Daum and Bormann 2004).

In response to the RPA of the $2003 \mathrm{BiOp}$, the Corps began removal of early-successional vegetation as an alternative to construction of tern and plover habitat. Fifteen acres of nesting habitat were created in spring 2004 at two sites in the Ft. Randall Reach (Daum and Bormann 2004). Efforts were moderately successful with six plovers and eight terns using one site. However, no young birds fledged from this site and no nests were established at the second site. In the fall of 2004, two additional sites were sprayed with herbicide and mowed, resulting in nesting use and good reproduction. Three additional sites that were sprayed and not mowed did not result in any successful nests. A similar approach was used in the fall of 2005 but at a larger scale, but fledging results were mixed. Dead plants were removed from these sites and all were used and most resulted in successful plover production. Most sites sprayed but not mowed in 2005 were mowed in 2007 and young birds fledged at about half of the sites (Corps 2008b).

Comparison of tern and plover productivity among treated (sprayed or sprayed and mowed) sites, newly constructed sites, formerly constructed sites, and natural unaltered habitats indicates newly constructed habitat exceeded productivity management goals, while sites treated to remove vegetation generally were far below management goals (Table 3). However, during 2005 productivity did exceed management goals at sites treated for vegetation control. Although management goals were exceeded in only 1 of 4 years, vegetation control methods were applied inconsistently. More information would likely show if vegetation control could effectively set back succession and produce either terns or plovers in excess of management goals (Corps 2008b). 
Table 3. Tern and Plover Productivity (fledglings/nest) Among Nesting Habitats of the Missouri River (Source: Corps 2008b)

\begin{tabular}{l|cc|cc|cc|cc|cc|c}
\hline \multirow{2}{*}{ Habitat } & \multicolumn{2}{|c|}{2004} & \multicolumn{2}{c|}{2005} & \multicolumn{2}{c|}{2006} & \multicolumn{2}{c|}{2007} & \multicolumn{2}{c}{ Avg. 2004-2007 } & \multicolumn{2}{c}{} \\
\hline Sprayed & Terns & Plovers & Terns & Plovers & Terns & Plovers & Terns & Plovers & Terns & Plovers & \\
Sprayed + Mowed & - & - & $\mathbf{0 . 0 0}$ & $\mathbf{0 . 0 0}$ & $\mathbf{0 . 7 9}$ & $\mathbf{0 . 4 2}$ & - & - & $\mathbf{0 . 7 8}$ & $\mathbf{0 . 4 0}$ & Vegetation \\
\hline New Created & $\mathbf{0 . 0 0}$ & $\mathbf{0 . 0 0}$ & 1.18 & 1.47 & $\mathbf{0 . 1 4}$ & $\mathbf{0 . 0 0}$ & $\mathbf{0 . 5 2}$ & $\mathbf{0 . 5 0}$ & $\mathbf{0 . 6 3}$ & $\mathbf{0 . 5 8}$ & Treatments \\
Old Created & 1.52 & 2.56 & 2.45 & 2.54 & - & - & 2.15 & 2.25 & 2.11 & 2.51 & \\
Unaltered & - & - & $\mathbf{0 . 3 5}$ & $\mathbf{0 . 3 8}$ & $\mathbf{0 . 6 5}$ & $\mathbf{1 . 2 4}$ & $\mathbf{0 . 3 3}$ & $\mathbf{0 . 4 3}$ & $\mathbf{0 . 4 9}$ & $\mathbf{0 . 7 9}$ & \\
\hline
\end{tabular}

Green: above productivity goal; black: near goal; red: below goal.

Researchers at the University of Nebraska at Lincoln tested a series of vegetation management practices in plots developed in 2007 and in 2008 on sandbars in Lewis and Clark Lake to develop methods to maintain sandbars free of vegetation (Knezevic et al. 2009). Soil amendments including lime (calcium carbonate) and ash (sodium carbonate) and the herbicide Imazapyr (Polaris AQ ${ }^{\circledR}$ ) were applied solely or in combination. Objectives included evaluating treatment effects on vegetation control and also impacts on invertebrate populations. Study plots were dominated by herbaceous species including cocklebur (Xanthium spp.), common ragweed (Ambrosia spp.), horsetail (Equisetum), marestail (Hippuris spp.), nutsedge (Cyperus spp.), sweet clover (Melilotus spp.), waterhemp (Amaranthus spp), and sunflower (Helianthus spp.) (Datta et al. 2009). Treatments included lime applied at three rates, ash (sodium carbonate) applied at three rates, and Imazapyr applied at two rates. All plots have been retreated with herbicide annually including in 2009. Monitoring of all plots occurred at 30, 90, 150, 390, and 730 days after treatment and is ongoing. Preliminary results indicate Imazapyr applied alone at $3 \mathrm{qt} / \mathrm{ac}(1.68 \mathrm{~kg} / \mathrm{ha}$ ) appears to control vegetation best during the year of application as well as the following year (Fig. 4-1) (Datta et al. 2009; Knezevic et al. 2009). Both soil amendments, applied solely, appear to have performed poorly compared to treatments including Imazapyr (Figures 7and 8).

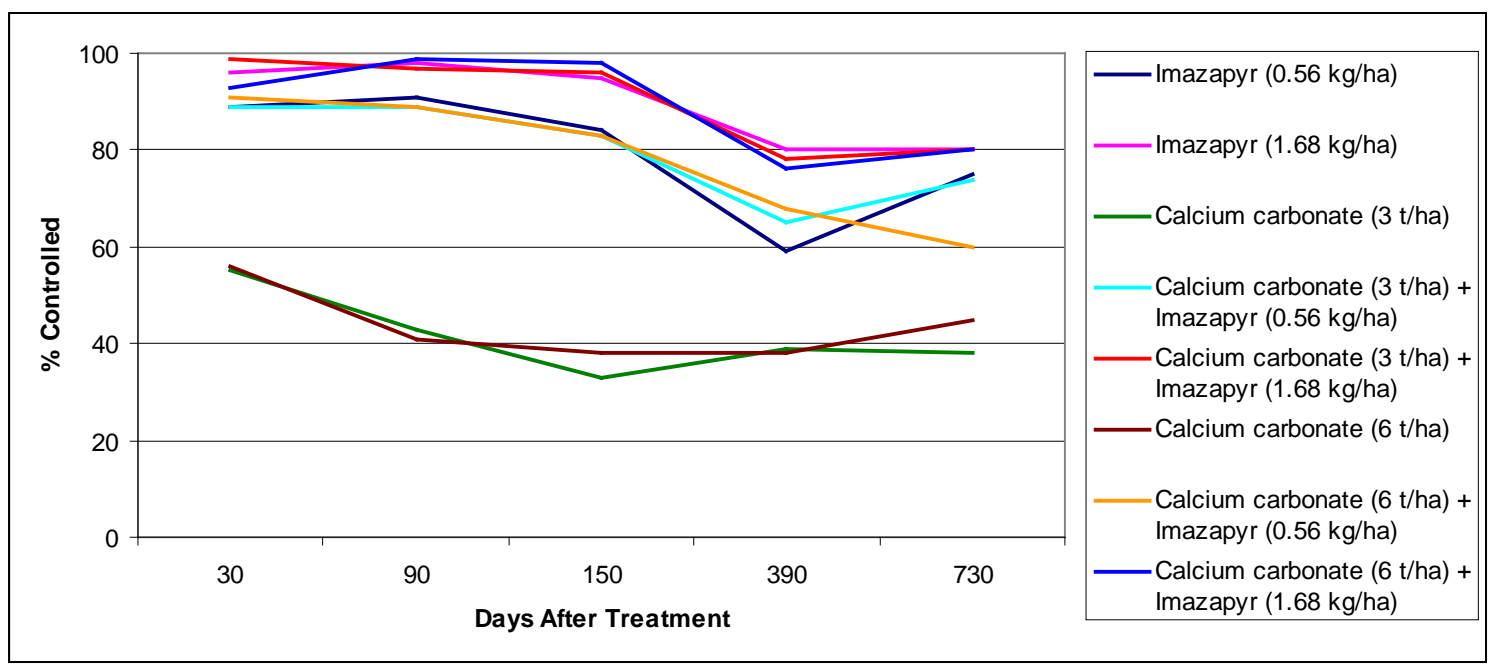

Figure 7. Control of Vegetation by Various Treatments of Lime (Calcium Carbonate) and the Herbicide Imazapyr on Sandbars of Lewis and Clark Lake (Data Source: Datta et al. 2009) 


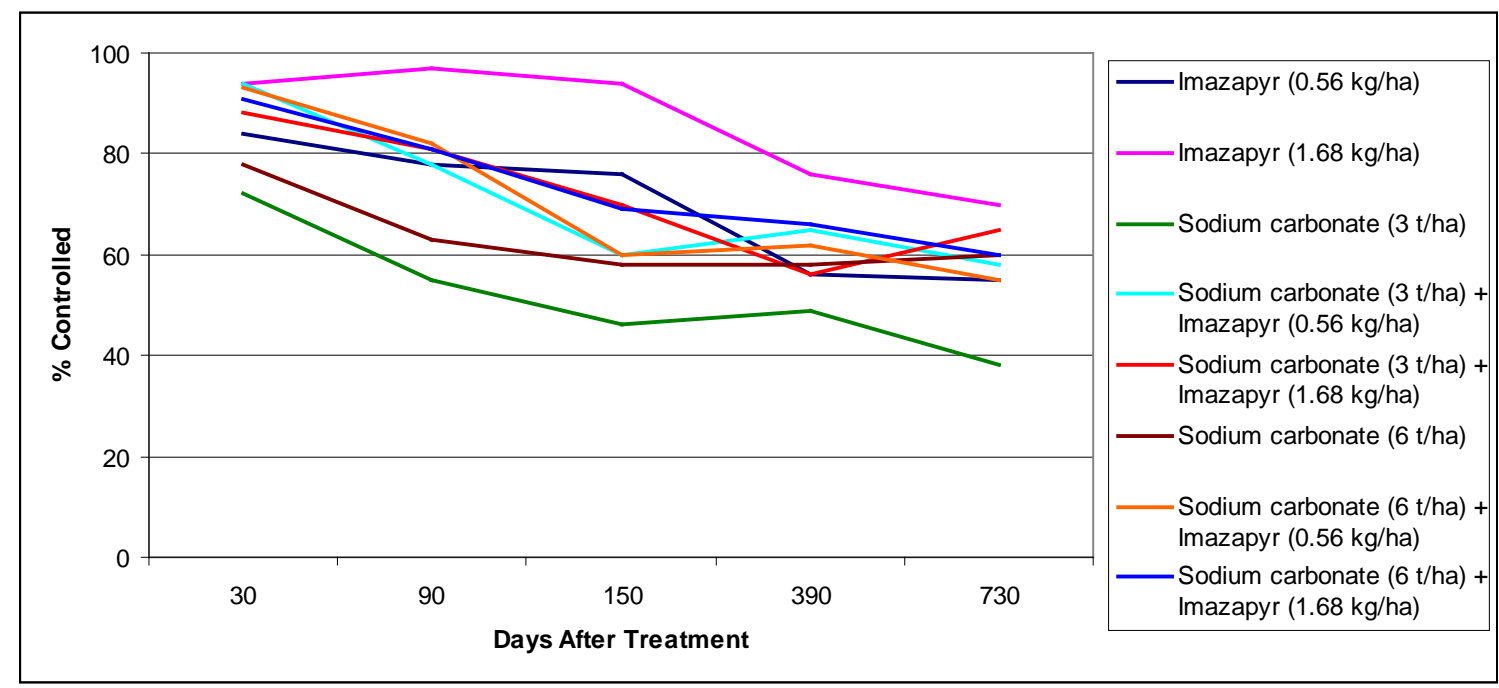

Figure 8. Control of Vegetation by Various Treatments of Ash (Sodium Carbonate) and the Herbicide Imazapyr on Sandbars of Lewis and Clark Lake (Data Source: Datta et al. 2009)

Germination studies were also conducted at two sandbars-Ponca at rm 755 and Yankton at rm 802.5 - to try to determine why these sandbars have not revegetated as is typical for sandbars; (Knezevic et al. 2009). Soil samples were collected and germination studies were conducted within growth chambers. Results indicated the samples had no viable seeds of any plant species. Corn, soybean, sweetclover, cocklebur, and common ragweed seeds were placed in soils from the two sandbars and showed excellent germination ( $>80 \%$ ), indicating there are no unique chemical or physical properties within the soils to prevent germination of these plants. During the winter 2009, additional trials were conducted using cattail (Typha spp.), common reed (Phragmites spp.), sandbur, sand dropseed (Sporobolus cryptandrus), and Canada thistle (Cirsium arvense). Results of this research were not available at the time of this writing, but could be important because these species better represent herbaceous plants found on ESH.

Based on the response of terns and plovers to initial sandbar vegetation management and findings of subsequent research efforts, the Corps began a study in 2009 to systematically determine the efficacy of various vegetation controls for restoring nesting habitat for terns and plovers (Corps 2008b). A variety of techniques used alone or in combination has been proposed to control vegetation: herbicide, root-ripping, mowing, debris removal, and overtopping (Table 4). A post-emergent glyphosate herbicide called AquaNeat ${ }^{\circledR}$ was proposed to be applied in the late summer/early fall. Root-ripping, performed with a cultivator without blades, is also conducted in the fall and is designed to remove dead vegetation following herbicide treatment. Mowing is designed to reduce the height of existing vegetation to about 2 to 3 in. Debris removal follows mowing and involved raking of stubble remaining after mowing. Overtopping, the deposition of sand to a depth of 6 in. above any remaining stubble, was proposed using nearby sands that have been recently inundated to reduce or eliminate viable plant seeds.

Imazapyr (Polaris $\mathrm{AQ}^{\circledR}$ ) would be applied as a pre-emergent herbicide in spring following fall treatments. A total of 15 test sites were used, each about 0.1 ac in size and distributed throughout five reaches of the Missouri River. Each site was divided into $25-\mathrm{m}^{2}$ test plots for application of various treatments. 
Table 4. Proposed Vegetation Removal Treatment Combinations (Source: Corps 2008b)

\begin{tabular}{|c|c|c|c|c|c|c|}
\hline \multirow{2}{*}{$\begin{array}{c}\text { Season } \\
\\
\text { Treatment }\end{array}$} & \multicolumn{5}{|c|}{ Fall } & \multirow{2}{*}{ Spring } \\
\hline & 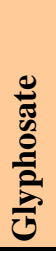 & 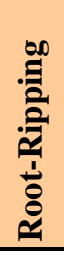 & ${ }_{\sum}^{000}$ & 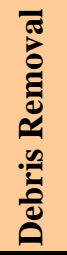 & 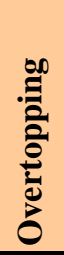 & \\
\hline 1 & $\mathbf{X}$ & $\mathbf{X}$ & & & & $X$ \\
\hline 2 & $\mathbf{X}$ & & $\mathbf{X}$ & $\mathbf{X}$ & & $\mathbf{X}$ \\
\hline 3 & $\mathbf{X}$ & & $\mathbf{X}$ & & $\mathbf{X}$ & $\mathbf{X}$ \\
\hline 4 & & & $\mathbf{X}$ & $\mathbf{X}$ & & $\mathbf{X}$ \\
\hline 5 (control) & & & & & & \\
\hline
\end{tabular}

In 2009, four treatments (root-rip, glyphosate and mow, overtop, mow) were applied at test plots in the Gavins Point, Fort Randal, and Garrison reaches along with a control plot (Stirling et al. 2010). Preliminary data indicate all treatments resulted in a reduction in plant material on the test plots. Results appeared similar among reaches and different habitat classes. Overtopping with sand appeared to be the most effective at reducing vegetation, but it was noted this method also reduced small and large debris that may be important to nesting terns and plovers. However, these results are only from the initial year of treatment. Spring application of pre-emergent Imazapyr was planned during 2010 on the plots treated in 2009, and further monitoring and analysis are required before valid conclusions can be drawn from this research.

\subsection{Additional Research}

During the course of conducting research on productivity and habitat use of constructed ESH, observational data were recorded and sometimes published that may not have related directly to research objectives. Also, additional research was conducted that was ancillary to the main objectives of the focused research presented in the previous section of this document. This section summarizes these observations and ancillary research.

\subsection{Piping Plovers}

\subsubsection{Banding}

During 2006, two piping plovers banded in Canada were observed foraging in Gavins Point Reach (Catlin and Fraser 2010b). In 2008, five plovers marked at other locations were observed early in the nesting season; two from Canada, one from the Great Lakes, and two others were unknown (Felio et al. 2010). None were known to nest along the Missouri River. A single plover banded in Alberta, Canada, was observed in August and a plover banded as a chick in Saskatchewan, Canada, nested at Lewis and Clark Lake in 2008. 


\subsubsection{Habitat Selection}

In 2006, McGowan et al. (2007) noted piping plover nests in atypical habitat on a natural sandbar. Fifteen nests were located during routine nest searching on a Gavins Point natural sandbar, and four of these nests occurred in habitat dominated by cottonwood and willow. Vegetation height ranged from 0.2 to $1.8 \mathrm{~m}$, and stem density ranged from 1 to $9 \mathrm{stems} / \mathrm{m}^{2}$. Of these four nests, eggs hatched in only one nest.

\subsubsection{Population Modeling}

Using data acquired on 16 selected sandbars (12 natural, 4 engineered) within the Gavins Point Reach and Lewis and Clark Lake from 2005 through 2007, Catlin (2009) modeled population growth. Productivity on these sandbars was higher during the 2005-2006 than in 2006-2007 timeframe. Model results indicated that the Gavins Point Reach piping plover population grew about 2\% annually from 2005 through 2007. The population of plovers using engineered habitat grew 3\% annually, while plovers nesting on natural sandbars declined 1\% (Catlin 2009).

\subsection{Implications of ESH Construction and Management Actions on Terns and Plovers}

Management implications provided here are driven mostly by plover nesting ecology and response to management actions because much more information about the piping plover is available on the Missouri River. Although piping plovers and least terns use similar nesting habitat along the Missouri River and often nest on the same sandbar, management actions derived from information based on plover ecology may not have the desired effects on least terns. As more information about least tern nesting ecology and response to management actions becomes available, management implications provided in this report may have to be revised.

Construction of ESH has resulted in a net gain of tern and plover nesting habitat, and both piping plovers and least terns successfully nest and fledge young on constructed sandbars. ESH construction has helped contribute to the recovery of both species and has been demonstrated as an ecological alternative for creation of nesting habitat. Research indicated that both juvenile and adult plovers preferred constructed sandbars over natural sandbars within Gavins Point Reach and Lewis and Clark Lake. These conclusions indicate that constructed ESH functions as piping plover nest habitat and was often preferred over natural sandbars.

The preference of constructed sandbars over natural sandbars may be an artifact of sandbar age. Most natural sandbars were created before or during the 1997 flood event. Erosion and more importantly succession has been acting on these sandbars for some time. Construction of sandbars began in 2004. Tern and plover nesting activity and productivity on constructed sandbars is highest during the first and second nesting seasons following construction. Clearly the life history of both least terns and piping plovers has evolved around taking advantage of recently created or altered habitats, indicating that they are pioneer species that often require dynamic environments to thrive. Succession, or the establishment of vegetation on exposed sandbars, appears to affect the availability and viability of constructed ESH as optimal tern or plover nesting habitat. Vegetated areas were avoided by least terns, while piping plovers 
were somewhat tolerant of sparse woody vegetation. Management of vegetation, both on natural and constructed ESH, could set back succession and provide the necessary disturbance to increase the number of seasons sandbars function optimally as nesting habitat. Initial attempts at testing the effectiveness of vegetation control in the late 1980s-early 1990s yielded mixed results. Treating sandbars mechanically and chemically in combination was successful in controlling weeds and attracting nesting terns and plovers. In 2005, sandbars sprayed and mowed exceeded both tern and plover productivity goals. However, other years under this vegetation control regime did not meet these goals. Continued systematic refinement of vegetation management methods should provide additional information to evaluate the usefulness of vegetation control as a tool to increase the viability and longevity of both natural and constructed ESH as nesting and foraging habitat.

Erosion also reduces the quantity and quality of available ESH. Through 2008, approximately 39\% of all constructed habitat no longer existed. However, over $60 \%$ of constructed ESH acreage lost to erosion occurred at two atypical sites—rm 755.0 and rm 770.0. Erosion has only reduced the aerial extent of the remaining six ESH construction sites by $21 \%$. The formation of cut banks along one or more sides on almost all constructed sandbars may reduce the amount of wet sand foraging habitat available for piping plovers. This loss and its effects have not been quantified, but it shouldn't affect nesting terns that forage on fish and do not use shallow-sloping sandbar banks. Although wind, water, and ice will continue to erode ESH constructed in a dynamic environment, the Corps can also continue to refine engineering of constructed ESH to not only better serve terns and plovers as nesting and brood rearing habitat, but also to increase the life of constructed ESH. 


\subsection{References}

50 FR 21784-21792. May 28, 1985. "Endangered and Threatened Wildlife and Plants; Interior Population of the Least Tern Determined to Be Endangered.” Federal Register. U.S. Fish and Wildlife Service.

50 FR 50726-50734. December 11, 1985. "Determination of Endangered and Threatened Status for Piping Plover.” Federal Register. U.S. Fish and Wildlife Service.

Catlin DH and JD Fraser. 2010a. Great Plains Plover Project 2005: Factors Affecting Piping Plover Nesting Density and Population Numbers on the Missouri River, on Created and Natural Bars-Field Operations Report 2005. Technical Report submitted to the Omaha Corps by the Virginia Tech University, Department of Fisheries and Wildlife, Blacksburg, Virginia.

Catlin DH and JD Fraser. 2010b. Great Plains Plover Project 2006: Factors Affecting Piping Plover Nesting Density and Population Numbers on the Missouri River, on Created and Natural Bars-Field Operations Report 2006. Technical Report submitted to the Omaha Corps by the Virginia Tech University Department of Fisheries and Wildlife, Blacksburg, Virginia.

Catlin DH and JD Fraser. 2010c. Great Plains Plover Project 2007: Factors Affecting Piping Plover Nesting Density and Population Numbers on the Missouri River, on Created and Natural Bars-Field Operations Report 2007. Technical Report submitted to the Omaha Corps by the Virginia Tech University, Department of Fisheries and Wildlife, Blacksburg, Virginia.

Catlin DH 2009. "Population Dynamics of Piping Plovers (Charadrius melodus) on the Missouri River." PhD Dissertation, Virginia Tech University, Blacksburg, Virginia.

Datta A, S Knezevic, C Shapiro, J Scott, and M Mainz. 2009. "Effects of Calcium Carbonate, Sodium Carbonate, and Imazapyr for Vegetation Control on Sandbars along Missouri River.” Poster presented at the North Central Weed Science Society Annual Meeting.

Daum DL and ER Bormann. 2004. Arsenal Vegetation Control Study. Internal Report, U.S. Army Corps of Engineers, Yankton, South Dakota.

Elzinga CL, DW Salzer, and JW Willoughby. 1998. Measuring and Monitoring Plant Populations. Technical Reference 1730-1, Bureau of Land Management, Denver, Colorado.

Felio JH, DH Catlin, and JD Fraser. 2010a. Great Plains Plover Project 2008: Evaluating Piping Plover Population Dynamics and Engineered Sandbar Habitat - Field Operations Report 2009.

Technical Report submitted to the Omaha Corps by the Virginia Tech University Department of Fisheries and Wildlife, Blacksburg, Virginia.

Felio JH, DH Catlin, and JD Fraser. 2010b. Great Plains Plover Project 2009: Evaluating Piping Plover Population Dynamics and Engineered Sandbar Habitat - Field Operations Report 2009. Technical Report submitted to the Omaha Corps by the Virginia Tech University, Department of Fisheries and Wildlife, Blacksburg, Virginia.

Haig SM, CL Ferland, FJ Cuthbert, J Dingledine, JP Goossen, A Hecht, and N McPhillips. 2005. “A Complete Species Census and Evidence for Regional Declines in Piping Plovers.” Journal of Wildlife Management 69(1):160-173. 
Huber CH, M Sherfy, and M Anteau. 2009. "Habitat Evaluation of Emergent Sandbar Habitat Creation Projects.” Missouri River Natural Resource Committee Conference and BiOp Forum, March 25-27, 2009, Billings, Montana.

Knezevic SZ, Z Datta, C Shapiro, J Scott, and M Mainz. 2009. Total Vegetation Control on Sandbars along the Missouri River Utilizing Lime, Sodium Carbonate (ash), and Herbicides: Yearly Report 2008/2009. Internal Report Submitted to the Corps Omaha District, Omaha, Nebraska.

Larson MA, MR Ryan, and BG Root. 2000. "Piping Plover Survival in the Great Plains: An Updated Analysis.” Journal of Field Ornithology 71(4):721-729.

Latka RJ, DC Latka, and RS Nebel. 1993. "Island Clearing and Habitat Improvement for Least Tern and Piping Plover Nesting Habitat along the Missouri River Main-stem System, 1987-1992.” In:

Proceedings of The Missouri River and Its Tributaries: Piping Plover and Least Tern Symposium. KF Higgins and MR Brashier (eds.), South Dakota State University, Brookings, South Dakota.

Le Fer D, JD Fraser, and CD Kruse. 2008. "Piping Plover Chick Foraging, Growth, and Survival in the Great Plains.” Journal of Wildlife Management 72(3):682-687.

McGowan CP, DH Catlin, GD Jons, and GA Pavelka. 2007. "Piping Plovers Nesting Amongst Cottonwood Saplings.” Waterbirds 30(2):275-277.

Missouri River Recovery Program. 2010. “Missouri River Recovery Program Website.” Accessed June 21, 2010, at http://www.moriverrecovery.org.

Sandercock BK. 2006. Estimation of Demographic Paramenters from Live-Encounter Data: A Summary Review. Journal of Wildlife Management 70(6):1504-1520.

Sherfy MH, MJ Anteau, TL Shaffer, MA Sovada, and JH Stucker. 2009a. Research, Monitoring, and Assessment Program for Least Tern and Piping Plover Habitat and Productivity on the Missouri River2009 Annual Report. Technical Report submitted to the Omaha Corps by the USGS Northern Prairie Wildlife Research Center, U.S. Geological Survey, Jamestown, North Dakota.

Sherfy MH, MJ Anteau, TL Shaffer, MA Sovada, LL Strong, and JH Stucker. 2009b. Research, Monitoring, and Assessment Program for Least Tern and Piping Plover Habitat and Productivity on the Missouri River - 2008 Annual Report. Technical Report submitted to the Omaha Corps by the USGS Northern Prairie Wildlife Research Center, U.S. Geological Survey, Jamestown, North Dakota.

Sherfy MH, MJ Anteau, TL Shaffer, MA Sovada, LL Strong, and JH Stucker. 2008. Research, Monitoring, and Assessment Program for Least Tern and Piping Plover Habitat and Productivity on the Missouri River - 2007 Annual Report. Technical Report submitted to the Omaha Corps by the USGS Northern Prairie Wildlife Research Center, U.S. Geological Survey, Jamestown, North Dakota.

Sherfy MH, JH Stucker, and DA Buhl. 2011. Selection of Nest-site Habitat by Interior Least Terns in Relation to Sandbar Construction. Journal of Wildlife Management (In Press).

Stirling JA, CJ Huber, MJ Anteau, and MH Sherfy. 2010. Evaluation of Removal and Control Methods to Create Emergent Sandbar Habitat on the Upper Missouri River. Oral Presentation at the Missouri River Natural Resources Committee Conference and BiOp Forum, March 17-19, 2010, Nebraska City, Nebraska. Abstracts available at http://mrnrc2010.com. 
Stucker JH, DA Buhl, and MH Sherfy. 2011. “Emergent Sandbar Construction for Least Terns on the Missouri River: Effects on Forage Fish in Shallow Water Habitats.” River Research and Application (In Press).

U.S. Army Corps of Engineers (Corps). The Missouri River Recovery Program Tern and Plover Data Management System (DMS). Online Data Source:

https://rsgis.crrel.usace.armiy.mil/intro/dms.dmsintro.main.

U.S. Army Corps of Engineers (Corps). 2010. Office Report: Emergent Sandbar Habitat Pedestrian Survey 2009. Omaha District, Sedimentation and Channel Stabilization Section, Omaha, Nebraska.

U.S. Army Corps of Engineers (Corps). 2009. Office Report: Emergent Sandbar Habitat Pedestrian Survey 2008. Omaha District, Sedimentation and Channel Stabilization Section, Omaha, Nebraska.

U.S. Army Corps of Engineers (Corps). 2008a. Office Report: Emergent Sandbar Habitat Pedestrian Survey 2007. Omaha District, Omaha, Nebraska.

U.S. Army Corps of Engineers (Corps). 2008b. Final Environmental Assessment for the Evaluation of Vegetation Removal Methods to Create Emergent Sandbar Habitat on the Upper Missouri River. Omaha District Environmental, Economics, and Cultural Resources Section Planning Branch, Omaha, Nebraska.

U.S. Fish and Wildlife Service. 2003. U.S. Fish and Wildlife Service 2003 Amendment to the 2000 Biological Opinion of the Operation of the Missouri River Main Stem Reservoir System, Operation and Maintenance of the Missouri River Bank Stabilization and Navigation Project, and Operation of the Kansas River Reservoir System.

U.S. Fish and Wildlife Service. 1990a. Least Tern (Sterna antillarum) and Piping Plover (Charadrius melodus) Surveys on the Missouri River, South Dakota - 1989. Report submitted to the USACE Omaha District, Omaha, Nebraska.

Vander Lee BS. 2002. Completion Report: Evaluation of Least Tern and Piping Plover Habitat on the Missouri River. Internal Report, U.S. Army Corps of Engineers, Omaha District, Omaha, Nebraska. 


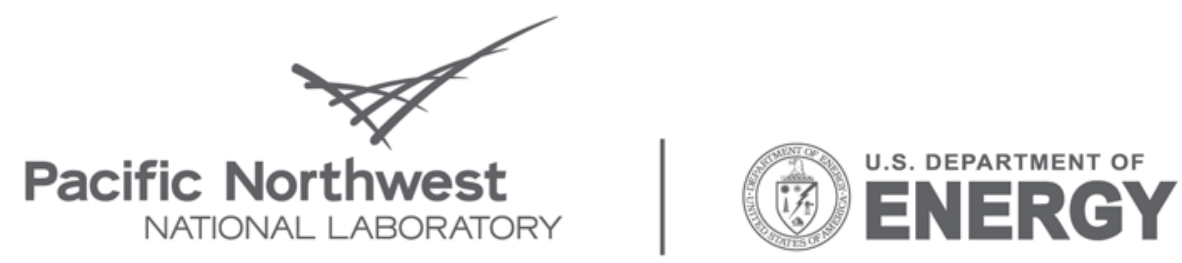

Proudly Operated by Battelle Since 1965

902 Battelle Boulevard

P.O. Box 999

Richland, WA 99352

1-888-375-PNNL (7665)

www.pnl.gov 